\title{
INSURANCE AGAINST CATASTROPHE: GOVERNMENT STIMULATION OF INSURANCE MARKETS FOR CATASTROPHIC EVENTS
}

\author{
VÉRONIQUE BRUgGEMAN, MichaEl FAURE \& TOBIAS HELDT $\dagger$
}

INTRODUCTION

As a result of climate change, technological development, and other variables, natural and technological catastrophes have increased dramatically. ${ }^{1}$ Moreover, due to infrastructural issues, such as building in floodplains, damages resulting from catastrophes have increased as well. ${ }^{2}$ The massive earthquake and tsunami that occurred in Japan on March 11, 2011 are still fresh in people's memories, providing sobering illustrations of the extensive reach of such catastrophes.

After a catastrophe, which is defined for the purposes of this Article as an accident with large losses in either the number of victims or the amount of property damage, governments often intervene in the compensation of catastrophe victims. However, the organization of government intervention in the compensation varies from one country to another and from one disaster to another. Governments intervene either because no satisfying solution is available in the

$\dagger$ At the time of writing, Véronique Bruggeman was a Ph.D. researcher at the Maastricht European Institute of Transnational Legal Research (METRO) and a member of the Law Faculty of Maastricht University. She is currently working as a Catastrophe Model Product Manager for Risk Management Solutions in London. Michael Faure is connected to METRO and is a member of the Law Faculty of Maastricht University. He is also a faculty member at the Rotterdam Institute of Law and Economics of Erasmus University in Rotterdam. Tobias Heldt is a Ph.D. researcher at METRO and is connected to the Research Center for Nuclear Energy in Mol, Belgium. The authors are grateful to the participants in the thirteenth joint seminar of the European Association for Law and Economics and the Geneva Association in Milano in May 2009, as well as to participants in an October 2009 seminar of the Amsterdam Centre for Law and Economics for their useful comments on an earlier version.

1. See Laurens M. Bouwer, Have Disaster Losses Increased Due to Anthropogenic Climate Change?, 92 Bull. AM. MeteOrOlOGICAL SOC'Y 39, 43 (2011) (discussing increased economic losses resulting from climate change-influenced disasters).

2. See id. 
private market or to fulfill the requirements of existing compensation schemes. Political pressure for such intervention may also be large.

Private insurance markets for catastrophic risks may fail for a variety of reasons, and governments may try to intervene to stimulate the insurability of catastrophic risks or to take over insurance functions when markets fail. Demand for catastrophe insurance may be too low even though such insurance would result in increased utility for potential victims (as in the case of flood insurance). In other cases, risk-modeling calculations may be difficult or the damage that could potentially be caused by a catastrophe may overwhelm the capacity of insurance markets.

Government intervention in compensation for catastrophe victims can take a variety of forms. In some cases (for example, in France), the government forces potential victims to purchase comprehensive insurance; in others (for example, in the case of the California Earthquake Authority), the government replaces the primary insurer and directly provides coverage to potential disaster victims. In yet other situations (for example, with terrorism risk), the government acts as a reinsurer of last resort and intervenes when the magnitude of loss exceeds a specific threshold. The government may also provide an additional insurance layer-for example, in nuclear liability conventions, the government supplements compensation provided by the operator of the power plant. Finally, the government may provide direct compensation to victims of catastrophes either through structural fund solutions or on an ad hoc basis.

These various forms of government intervention have been criticized in the literature. Most of the criticism concentrates on government provision of ex post compensation on an ad hoc basis. ${ }^{3}$ However, some critics also address the type of government intervention on which we focus in this Article-on the government acting as a facilitator of insurance markets or as a reinsurer of last resort. ${ }^{4}$ Notwithstanding the criticism, schemes in which the government facilitates the insurability of catastrophic risks-including terrorism and natural disasters-are on the rise. The importance of compensating victims of catastrophes (after 9/11, the focus was

3. See generally Richard A. Epstein, Catastrophic Responses to Catastrophic Risks, $12 \mathrm{~J}$. RISK \& UnCERTAINTY 287 (1996); see also Michael G. Faure, Financial Compensation for Victims of Catastrophes: A Law and Economics Perspective, 29 L. \& POL'Y 339 (2007).

4. See Anne Gron \& Alan O. Sykes, A Role for Government?, 25 REG. 44, 44 (2002) [hereinafter Role for Government]; see also Anne Gron \& Alan O. Sykes, Terrorism and Insurance Markets: A Role for the Government as Insurer?, 36 IND. L. REV. 447, 448 (2003). 
strongly on terrorism; after Katrina, flooding came to the forefront; and after the Japanese earthquake and tsunami, compensation for victims of those risks soared on the political agenda) gives rise to the question whether such a government role should indeed be considered problematic, especially when compared with the alternative of providing outright ex post compensation to victims on an ad hoc basis. This is the main question we will address in this Article.

Our paper is structured as follows: we first identify the various types of government intervention in compensating victims of catastrophes. Next, we focus specifically on the types of government intervention that stimulate insurability of catastrophic risks and analyze how these forms of intervention can be considered from a law-and-economics perspective. Then, we focus more particularly on the role of government as a (re)insurer of catastrophic risks and sketch the conditions under which such intervention may be effective. Finally, we compare these starting points with several cases (relating to both terrorism and natural disasters) in which the government stimulates insurability.

\section{TYPES OF GOVERNMENT INTERVENTION IN COMPENSATION FOR CATASTROPHES}

Natural catastrophes, industrial disasters, and terrorist attacks pose a number of challenges for insurers. These catastrophes involve very large losses that occur only rarely, and this requires large financial reserves to be built up over time. Pricing catastrophe insurance products is complicated by a number of factors, including the difficulty of predicting the frequency and probability of catastrophic accidents and their related losses (although some catastrophe-modeling firms have made such calculations the core of their business). ${ }^{5}$ Spreading the risk of catastrophe losses over a sufficiently large base of buyers is also difficult and makes it harder for insurers to offer affordable products. ${ }^{6}$ Given these obstacles, the traditional insurance sector will increasingly have to rely upon the reinsurance (i.e. insurance for insurance companies) market to

5. See Zurich Am. Insurance Co., CAtastrophe Risk And the Cost of ReAL ESTATE INSURANCE POLICIES (2009), available at http://www.zurichna.com/internet/zna/ sitecollectiondocuments/en/media/whitepapers/rewhitepapercatastropherisk.pdf.

6. See Michael Faure \& Véronique Bruggeman, Catastrophic Risks and First-Party Insurance, 15 CONN. INS. L.J. 1, 21 (2008) (discussing the lack of demand for first-party disaster coverage). 
recompense catastrophic damages to the victims. However, Professor Kenneth Froot found that insurers generally use reinsurance to cover only a small fraction of the financial exposure of households and firms to catastrophic natural disasters. ${ }^{7}$ This is all the more worrying because many primary insurance companies do not have enough capital and surplus themselves to survive medium and large catastrophes. ${ }^{8}$

Admittedly, the Solvency II Directive ${ }^{9}$ mitigates this situation to a certain extent because insurers and reinsurers are obliged to have sufficient capital in their reserves for all of the risks that they are facing. This reduces the risk of insolvency; however, it does not eliminate the possibility of insufficient capital in case of a large-scale catastrophe. In sum, both insurance and reinsurance markets may fail, given that the losses resulting from mega-disasters may be too large for the reinsurers' financial capacities. ${ }^{10}$

Given these difficulties, what role can be granted to the government in the context of financing compensation for victims of catastrophes? More particularly, how can the state improve the functioning of catastrophe (re)insurance markets? The government can take several seemingly different approaches in crafting policies for managing catastrophe risks and compensating attendant losses. ${ }^{11}$ "First, the government can rely primarily on the private insurance market." ${ }^{12}$ Second, the government can provide direct compensation to the catastrophe victims. ${ }^{13}$ Third, the government can institute mandatory comprehensive insurance. Fourth, the government itself

7. Kenneth A. Froot, The Financing of CAtastrophe Risk 1, 2 (Kenneth A. Froot ed., 1999).

8. See id.: see also VÉRONiQUe BRUgGeman, COMPENSATING CATASTrophe Victims: A COMPARATIVE LAW AND ECONOMICS APPROACH 136 (Kurt Deketelaere et al. eds., 2010).

9. See Directive 2009/138, of the European Parliament and of the Council of 25 November 2009 on the Taking-Up and Pursuit of the Business of Insurance and Reinsurance (Solvency II), 2009 O.J. (L 1104) 1, 24.

10. The high catastrophe losses sustained in the first half of 2011 have already had an impact on capital and pricing in the reinsurance market. Since the January 1, 2011 insurance contracts renewal, the decline in the capital positions of some reinsurers has exerted pricing pressure on catastrophe-exposed markets. See Guy Carpenter, WORLD CATASTROPHE REINSURANCE MARKET REVIEW 6 (September 2011), available at_http://www.guycarp.com/ portal/extranet/insights/reportsPDF/2011/World\%20Catastrophe\%20Report\%202011.pdf;jsessi onid=Pp8bH0fPwZX3cnp53yR4Fzr2tBZFrs6GW2TLJ7FLhJB0ZGdn9HpQ!-

1763263147? vid $=2$.

11. BRUGGEMAN, supra note 8, at 187.

12. Id. at 188 .

13. Id. 
can provide catastrophe insurance. "[Fifth,] the government can share the catastrophe risk with the private sector by acting as a reinsurer of last resort." ${ }^{14}$ Sixth, the government can finance catastrophic damages through an additional insurance layer above the insurers' own financing. Finally, new forms of government intervention, such as acting as a lender of last resort, have been proposed. Government intervention can also include a combination of any of these mechanisms. ${ }^{15}$

The remainder of this section will discuss the various ways in which the government can intervene in compensating victims of catastrophes, along with providing relevant examples. In some cases, government intervention can be insurance-related or can stimulate insurability, whereas in others, government does not take any insurance objectives into account. The main thrust of our article is that government collaboration with insurance markets is generally preferred over mechanisms in which such collaboration is absent.

\section{A. Relying on the Private Insurance Market ${ }^{16}$}

This approach entails the least amount of government intervention in catastrophe insurance markets. The government does not assume any risk for losses covered by catastrophe insurance. Instead, it focuses on removing barriers that limit the ability of insurance markets to provide catastrophe coverage.

Various options for increasing capacity of private insurance markets are open to the government. First, federal regulations can be relaxed to encourage the issuance of catastrophe bonds (for example, by making it easier to issue bonds for which the principal and not just the interest of the bondholder is at risk). Second, and especially relevant for the United States, accounting standards and tax laws can be adapted so that private insurers can establish reserves in anticipation of catastrophic events on a tax-free basis. The idea is that if insurance firms hold sufficient capital and reserves, then the risk of ruin from a catastrophic event can be reduced to a manageable level, thus allowing for the emergence of a private market for catastrophe insurance. ${ }^{17}$ Third, government can help set up a voluntary pool of numerous insurers active in the catastrophe insurance market. Mutual

14. Id.

15. Id.

16. Part I.A borrows from a book written by one of the authors: BRUGGEMAN, supra note 8 , at 188 . To ease readability, quotation marks have been omitted.

17. This is one of the purposes of the European Solvency II Directive. 
risk retention pools, organized within the private markets, help create private markets for the provision of catastrophe insurance. Of course, these options might allow insurers to cover larger losses than they would be able to cover otherwise, but it is still unlikely that the industry would be able to cover the largest of losses. Nevertheless, they may, in some cases, be sufficient to activate or reactivate private catastrophe insurance markets, as evidenced by two examples from the United States. ${ }^{18}$

Evidence of the U.S. government helping the catastrophe insurance market is "provided by two features of the quasi-public agencies created to provide insurance coverage for wind damage (Florida) and earthquakes (California), ${ }^{19}$ the Florida Hurricane Catastrophe Fund and the California Earthquake Authority (CEA), respectively.

First, the capital raised by each agency is available only for paying claims on its natural disaster coverage, since the quasi-public agencies are fully protected against any take-over attempts by private market firms . . The accounting rules that otherwise preclude the earmarking of capital to specific expected catastrophe losses are hereby circumvented. Second, both agencies acquired special tax exemptions from the Internal Revenue Service (IRS, the US tax authority). Both of the above discussed accounting and taxation issues were hereby solved, and this was essential to their success in reviving activity in their respective natural disaster markets. However, it is intriguing that the US accounting and tax authorities appear unwilling to provide similar opportunities to private sector entities. ${ }^{20}$

\section{B. Providing Direct Compensation to Victims of Catastrophes}

In many situations, governments provide generous ex post compensation to victims of a catastrophe. The motivations for these interventions may vary. In some cases, it is argued that, out of solidarity, public funds should be used to provide (partial) compensation to victims. ${ }^{21}$ In other cases (this may be an especially strong argument in case of terrorist attacks), the government may be

18. DWIGHT M. JAFFEE, REPORT ON THE ROLE OF GOVERNMENT IN THE COVERAGE OF TERRORISM RISKS 21 (2004).

19. Id.

20. Id.

21. See Jef Van Langendonck, International Social Insurance for Natural Disasters?, in ShifTs In COMPENSATION BETWEen PRIVATE AND PUBliC SYSTEMS 183, 192-93 (Willem H. Van Boom \& Michael Faure eds., 2007). 
best placed to take preventive measures. ${ }^{22}$ If these preventive measures have not been taken, direct compensation through public funds can provide alternative means for the government to live up to its responsibilities.

Ex post compensation by the state can be ad hoc or of a structural nature. In the case of ad hoc compensation, "the government decides in each case, depending upon the size of the catastrophe, whether public funds will be made available or not ${ }^{233}$ and if so, to what amount. In contrast, one example of a structural solution is the institution of a compensation fund for victims of natural catastrophes.

Examples of structural direct compensation to victims of catastrophes can be found in many legal systems. Austria established a fund for catastrophes in 1996, which is "financed from income and corporate taxes and only covers part of the property damage suffered by victims of a catastrophe. ${ }^{24}$ Belgium established a structural fund in $1976{ }^{25}$ however, the importance of the fund has recently been seriously reduced due to the introduction of mandatory comprehensive insurance in Belgian legislation. ${ }^{26}$ Structural funds also exist in the United States, where:

[t]he Federal Emergency Management Agency (FEMA) distributes -inter alia to local governments-substantial amounts from its disaster relief fund ... [but] most of [the] federal assistance through FEMA is provided as emergency aid, hazard mitigation assistance, or public assistance to communities. It is therefore not comparable with a [structural] compensation fund that directly pays compensation for damage to victims, as is the case in Austria or Belgium. ${ }^{27}$

There are also numerous examples of ad hoc solutions that provide immediate disaster relief for specific cases. A well-known example in the United States is the September 11th Victim

22. Id.

23. Faure, supra note 3, at 353.

24. Michael Faure, Comparative and Policy Conclusions, in FinANCIAL COMPENSATION FOR Victims of CATASTRophes: A COMPARATIVE Legal ApProACH 389, 415 (Michael Faure and Ton Hartlief eds., 2006), citing Dagmar Hinghofer-Szalkay \& Bernhard A. Koch, Austria, in Financial Compensation for Victims of CATASTRophes: A Comparative LEGAL APPROACH 7, 12 (Michael Faure and Ton Hartlief eds., 2006).

25. See Isabelle C. Durant, Belgium, in FinANCIAL COMPENSATION FOR ViCTIMS OF CAtastrophes: A Comparative Legal ApProACH 37, 59-69 (Michael Faure and Ton Hartlief eds., 2006).

26. Id.

27. Faure, supra note 24, at 417-18. 
Compensation Fund. ${ }^{28}$ The fact that compensation is provided on an ad hoc rather than a structural basis does not mean that the amounts of compensation will be lower.

For example, in Germany after the "flood of the century" of the river Elbe in 2002, ad hoc compensation was provided through the so-called Flutopferhilfesolidaritätsgesetz, which provided a total amount of compensation of 8.1 billion euros. Also, in Italy the amounts paid by the Italian government as ad hoc compensation are on average 3.5 to 4 billion euros per year as a consequence of which a relevant share of the states' yearly budget is devoted to restoring damage as a result of catastrophes.

The Dutch government intervened with ad hoc compensation to the victims of the fireworks explosion in Enschede ${ }^{30}$ and the large café fire in Volendam. The young Volendam victims received a total of $€ 30.1$ million from the state, amounting to about $€ 150,000$ per victim, whereas the Enschede victims received only $€ 120,000$ per person. ${ }^{31}$ In the end, the national government in both instances not only provided compensation for the direct costs-as was initially the idea-but also provided large amounts of ad hoc compensation. Reports on (more or less generous) ad hoc ex post compensation have also come from many other countries. ${ }^{32}$ The efficiency of this type of government intervention will be further analyzed in Part II.A.

28. See Robert L. Rabin \& Suzanne A. Bratis, United States, in FinANCIAL COMPENSATION FOR Victims of CATASTROPHIES: A COMPARATIVE LEGAL APPROACH 7, 12 (Michael Faure and Ton Hartlief eds., 2006); see also MARSHALl S. SHAPO, COMPENSATION FOR VICTIMS OF TERRORISM 105-25 (2005); Kenneth P. Nolan \& Jeanne M. O'Grady, The Victim Compensation Fund-Looking a Gift Horse in the Mouth, 53 DEPAUL L. REV. 231 (2003); George L. Priest, The Problematic Structure of the September 11th Victim Compensation Fund, 53 DePaul L. REV. 527 (2003); Matthew Diller, Tort and Social Welfare Principles in the Victim Compensation Fund, 53 DEPAUL L. REV. 719 (2003).

29. Michael Faure \& Klaus Heine, Can European State Aid Control learn FROM THE MANAGEMENT OF DISASTROUS CRISES? 7, prepared for Ausschuss für Wirtschaftssysteme und Institutionenökonomik Verein für Socialpolitik (2010), available at http://www.wiwi.uni-muenster.de/06/vs/Tagungen/2010/Heine-Faure_Referat.pdf (citation omitted).

30. See Michael Faure \& Ton Hartlief, The Netherlands, in FInANCIAL COMPENSATION FOR Victims of CATASTRophes: A COMPARATIVE LEgAl APPROACH 195, 219-20 (Michael Faure \& Ton Hartlief eds., 2006).

31. Guido SuURmond, ENForcing Fire SAFETy IN THE CATERING INDUSTRY: AN ECONOMIC ANALYSIS 261 (Leiden Univ. Press, 2008).

32. For a comparative overview, see generally the contributions in FINANCIAL COMPENSATION FOR VICTIMS OF CATASTROPHES: A COMPARATIVE LEGAL APPROACH (Michael Faure \& Ton Hartlief eds., 2006). 


\section{Providing Mandatory Comprehensive Insurance}

In some cases, the government does not intervene to cure problems on the supply side of disaster insurance, but instead attempts to remedy information failures on the demand side. Empirical evidence demonstrates that even in countries where disaster insurance is widely available (such as in the United States and in Europe), individuals tend not to make sufficient use of it, resulting in dramatic cases of underinsurance. This became apparent after the "flood of the century" of the river Elbe in Germany ${ }^{33}$ and after Hurricane Katrina in the United States. ${ }^{34}$

There are several reasons for this low demand for disaster insurance. First, low-probability events like natural disasters are systematically misjudged ${ }^{35}$ resulting in an "it will not happen to me" attitude. ${ }^{36}$ Second, there is equally strong empirical evidence that people ex ante prefer large uncertain losses over smaller certain losses. Insurance is considered an investment; however, as the potential victim - for example, a homeowner-is confronted with the certain loss of a premium and a low expectation of a return on the "investment" during his lifetime, demand for this investment is low. ${ }^{37}$ Third, literature indicates that ex post government relief reduces incentives to purchase insurance coverage. ${ }^{38}$

The limited demand for disaster coverage can lead to legislative action to stimulate the availability of (affordable) insurance. In some

33. See, e.g., Alfred Endres, et al., 'Land unter!' Ein Institutionenökonomische Zwischenruf, 29 LIST FORUM FÜR WIRTSCHAFTS UND FINANZPOLITIK 284 (2003); see also Ulrich Magnus, Germany, in FINANCIAL COMPENSATION FOR VICTIMS OF CATASTROPHES: A COMPARATIVE Legal APPROACH 119, 124 (Michael Faure \& Ton Hartlief eds., 2006) (noting that because the magnitude of losses from the flood exceeded capacity, the solidarity of the public was required to provide adequate compensation); Reimund Schwarze \& Gert G. Wagner, In the Aftermath of Dresden: New Directions in German Flood Insurance, 29 THE GENEVA PAPERS ON RISK AND INS. 154, 154-55 (proposing an alternative mandatory form of natural hazard insurance based on pooling).

34. See generally ON RISK AND DISASTER: LESSONS FROM HURRICANE KATRINA (Ronald J. Daniels, Donald F. Kettl \& Howard Kunreuther eds., 2006).

35. See Paul Slovic, Howard Kunreuther \& Gilbert White, Decision Processes, Rationality and Adjustment to Natural Hazards, in THE PERCEPTION OF RISK 187, 187 (2000) (discussing decisionmaking responses to natural disasters in a technological society).

36. Howard Kunreuther, Mitigating Disaster Losses through Insurance, 12 J. RISK \& UNCERTAINTY 171, 175 (1996).

37. Paul Slovic et al., Preference for Insuring Against Probable Small Losses: Insurance Implications, 44 J. RISK \& INS. 237, 237 (1977).

38. See, e.g., Epstein, supra note 3, at 293-96; see also Scott E. Harrington, Rethinking Disaster Policy, 23 REG. 40, 41-46 (2000) (demonstrating the effects of moral hazard and adverse selection). 
cases, this goes as far as imposing mandatory coverage for the consequences of catastrophes. The economic rationale in favor of this system will be further developed in Part II.B.

France provides one of the best-known examples of this type of intervention. Through the Act of July 13, 1982, France created a duty in its "code des assurances" to provide coverage for the consequences of natural disasters in addition to "voluntarily purchased first-party insurance policies covering damage against property, as well as firstparty car insurance policies covering the insured value of the car and property left in it." ${ }^{39}$ This mandatory additional disaster coverage (in other words, catastrophe insurance must be bundled with ordinary car and home insurance) was introduced because such damage would normally be considered uninsurable. ${ }^{40}$ Insurers are only liable for such damages if the government declares a certain incident to be a natural disaster. ${ }^{41}$ The coverage for natural catastrophes is:

[A] percentage of the insurance premium paid by each insured and is decided upon by the Government, in the form of a Decree. In practice, this comes down to the 'national solidarity principle,' since every citizen and business firm will pay the same extra-charge rate whatever his or her exposure to the natural catastrophe risk .... Apart from the additional insurance premium, also the applicable and mandatory deductibles are fixed in a Decree. ${ }^{42}$

This French example of a mandatory comprehensive coverage system has recently been followed in Belgium. Through the Acts of May 21, 2003 and September 17, 2005, a mandatory extension for natural disasters (flooding, earthquakes, impoundment of public sewers, landslides, or subsidence) was added to the voluntarily purchased fire insurance coverage for so-called simple risks. ${ }^{43}$ As a result, ninety to ninety-five percent of the Belgian population has now been insured against such natural-catastrophe risks. "The insurer can investigate the natural hazard risk for every individual case and

39. Act No. 82-600 of 13 July 1982 on the Indemnification of Victims of Natural Catastrophes, JORF 2242 (1982); BRUGGEMAN, supra note 8, at 303.

40. See BRUGGEMAN, supra note 8, at 303 (offering an explanation of the French system where first-party insurance automatically includes natural disasters); see also Michel Cannarsa, Fabien Lafay \& Olivier Moréteau, France, in FINANCIAL COMPENSATION FOR VICTIMS OF CATAstrophes: A Comparative Legal Approach, (Michael Faure and Ton Hartlief eds., 2006) (offering a detailed description of mandatory disaster coverage).

41. See generally Olivier Moréteau, Policing the Compensation of Victims of Catastrophes: Combining Solidarity and Self-Responsibility, in SHIFTS IN COMPENSATION BETWEEN PRIVATE AND PUBLIC SYSTEMS 199-218 (Willem H. Van Boom \& Michael Faure eds., 2006).

42. BRUGGEMAN, supra note 8, at 306-07 (citation omitted).

43. See id. at 247-60 (describing in detail the Belgian system). 
will adjust the extra premium accordingly . . . . The final premium will hence differ in function of the real risk." ${ }^{, 44}$ The introduction of such a mandatory insurance scheme for disasters has also been proposed in German legal scholarship. ${ }^{45}$ A variety of legislative proposals with the same aim have also been introduced in Italy. ${ }^{46}$

\section{Government-Provided Insurance: Government Acting as Primary Insurer $^{47}$}

In the most extreme form of intervention in victim compensation, the government serves as the primary insurer, taking on all insurance functions, including defining the coverage, setting the prices, and bearing the risk. Such government intervention can take two forms: 1) complete and free government insurance; and 2) full government insurance by a quasi-public entity operating under constraints imposed by legislation. ${ }^{48}$ The former empowers a government, which defines the coverage, bears the risk, and plans to finance the costs from general tax revenues. ${ }^{49}$ Equitable considerations are one of the main motivations for this type of government intervention. ${ }^{50}$ However, complete government insurance also reduces the incentive for citizens to mitigate their actual losses in case of catastrophe. ${ }^{51}$ The second type of full government insurance involves a quasi-public entity, which is empowered to set premiums and bear the catastrophe risks under voluntary coverage. Legislation can then require large initial capital contributions to the agency from private insurance firms, which are thereby relieved of the need to

44. Id. at 256 .

45. See, e.g., Endres et al., supra note 33, at 284-94; see also Schwarze \& Wagner, supra note 33, at 163-67 (arguing that general mandatory insurance would protect against a wide variety of mega-disasters and force individuals to buy their own insurance instead of relying on government aid and donations).

46. See Alberto Monti \& Filippo Andrea Chiaves, Italy, in FinANCIAL COMPENSATION FOR ViCTIMS OF CATASTROPHIES: A COMPARATIVE LEGAL APPROACH 146, 186-91 (Michael Faure \& Ton Hartlief eds., 2006) (describing how the Italian government presented a bill in 1999 which would regulate all natural disaster insurance, and in 2001 Senator Manfredi presented a bill which would regulate private citizens' relationships with private disaster insurance companies).

47. Part I.D borrows from a book by of one of the authors, see BRUGGEMAN, supra note 8, at 190 . To ease readability, quotation marks have been omitted.

48. See JAFFEE, supra note 18 , at 24 .

49. Id.

50. Id.

51. See Jack Hirshleifer, War Damage Insurance, 35 REV. ECON. \& STAT. 144, 144-53 (1953) 
provide direct coverage. As a result, private insurance companies may and do compete with the government. However, this may crowd out wholly private competitors, who may eventually only offer coverage for low-risk locations and structures.

As mentioned above, equitable considerations supply the main motivation for providing complete and free government insurance. ${ }^{52}$ This motivation "would seem appropriate when the losses incurred are the result of a common national policy such as a war." ${ }^{, 53}$ Some countries, such as Israel and Northern Ireland, therefore offer coverage for losses due to terrorism to all persons without direct cost. ${ }^{54}$ The government bears the entire risk, which is funded from general tax revenues. ${ }^{55}$

In California, the CEA, ${ }^{56}$ created after the 1994 Northridge Earthquake, assumes primary responsibility for bearing earthquake risk, and the primary insurer plays an exclusively administrative role. ${ }^{57}$ The CEA thus "provides an example of full government insurance." The CEA is a quasi-public entity empowered to set premiums and bear risks under three constraints: 1) legislation determines the classes of real-estate losses which may and may not be covered ${ }^{59} 2$ ) legislation requires premiums be set on an "actuarial basis" (though, in practice, the quoted CEA premiums have been "tempered," moderating the price differences across regions) $;^{60}$ and 3) "legislation require[s] large initial capital contributions from []private insurance firms, which [are] thereby relieved of the need to provide direct coverage. The legislation allows CEA to purchase reinsurance, but denies CEA to have access to public funds." ${ }^{, 1}$

The National Flood Insurance Program (NFIP), administered by FEMA, is another example of government assuming the role of

52. JAFFEE, supra note 18 , at 24 .

53. Id.

54. Id.

55. Id.

56. The reader will notice that we mentioned the CEA in Part I.A as an example of relying on the private insurance market and here as government as primary insurer. The reason is that the CEA still relies on private insurers, but they merely administer the risk; risk-bearing was taken over by the government.

57. See FAURE \& HEINE, supra note 29, at 9-10.

58. Id. at 9 .

59. Id.

60. Id.

61. Id. 
primary risk insurer. ${ }^{62}$ The NFIP can be regarded as a variant on the CEA: like the state of California, the U.S. federal government has stepped in and assumed the risk of financial loss associated with a disastrous flood. The NFIP, created under the Housing and Urban Development Act of $1968,{ }^{63}$ is a joint private industry and federal government cooperative program enabling homeowners and businesses in participating communities to purchase subsidized insurance protection against losses from flooding. ${ }^{64}$ Subsidized insurance is provided to properties that were in existence at the time the area in which they are located was identified as a Special Flood Hazard Area (SFHA). ${ }^{65}$ The SFHA consists of land subject to a one percent or greater chance of flooding in any given year. Such areas are commonly referred to as subject to the one-hundred-year flood. ${ }^{66}$ "In exchange for the availability of subsidized insurance for existing buildings, communities are required to protect new construction and substantially improved structures through the adoption and enforcement of community floodplain management ordinances" or regulations. ${ }^{67}$ The NFIP thus consists of a quid pro quo arrangement: the federal government makes insurance available to community residents at subsidized rates in exchange for the adoption and enforcement of floodplain regulatory ordinances by community officials.

\section{E. Government-Provided Reinsurance: Government as a Reinsurer of Last Resort ${ }^{68}$}

Under this approach to government involvement in catastrophe insurance, the state assumes at least part of the risk for losses from

62. Fed. Emergency Mgmt. Agency, National Flood Insurance Program: PROGRAM DESCRIPTION 3 (2002).

63. Housing and Urban Development Act of 1968, Pub.L.No. 90-448, 82 Stat. 476 (1968).

64. Id.

65. Id.

66. The one-hundred-year flood represents a magnitude and frequency of flooding that has a statistical probability of being equaled or exceeded in any given year, or, stated alternatively, the one-hundred-year flood has-ironically (and reflective of public misperception of flood risks) - a 26 percent (or one in four) chance of occurring over the life of a thirty-year mortgage. The one-percent-annual-chance flood was chosen because it provides a high level of protection while not imposing overly stringent requirements or excessive costs on property owners. See Raymond J. Burby, Flood Insurance And Floodplain Management: The US Experience, 3 ENV'T HAZARDS 111-22 (2001).

67. FEMA, supra note 62, at 3 .

68. Part I.E borrows from a book written by one of the authors, see BRUGGEMAN, supra note 8 , at 189 . To ease readability, quotation marks have been omitted 
catastrophes. Although this approach requires government intervention (since the private insurance market cannot provide adequate catastrophe insurance coverage), the underlying philosophy is that private insurance should continue to play a significant role in allocating compensation for victims of catastrophes. Thus, this option usually takes the form of a multi-layered insurance program that is normally administered by private insurance companies that sell the insurance, collect premiums, and pay claims.

In one example of a multilayered insurance program, the first layer of (small) catastrophe losses is borne by the victims themselves to provide loss-reducing incentives and prevent moral hazard. Private insurance companies cover the second layer of catastrophe losses with risk-based premiums and coverage depending on the surplus of the insurer, its current portfolio, and its ability to diversify across risks. The third layer of losses is covered by reinsurance and catastrophe bonds, which are to be acquired by the primary insurers. Once these funds are exhausted, a government reinsurance program covers the fourth layer of risk, consisting of extreme losses. The government is, in other words, involved as a reinsurer of last resort.

If the government acts as a reinsurer of last resort, it mainly provides reinsurance at the highest risk levels, while primary insurers and reinsurers retain responsibility for some or all of the lower risk levels. The sharing of risk with private industry is achieved through a mandatory deductible limit at the lowest risk level and through coinsurance at intermediate risk levels. Various features of a government acting as a reinsurer of last resort can be considered, including, for example, the price of premiums for the government's reinsurance facility, mandatory or voluntary participation in the plan, establishment of the maximum retained risks and risk-coverage limitations, and the possibility of incorporating a sunset provision.

In any case, government involvement in insurance coverage for catastrophic events does not function like traditional insurance for the following reasons: ${ }^{69}$ (1) where premiums are charged, they may be explicitly subsidized or set based on incomplete measures of the risks involved, which may result in an implicit subsidy, even in the absence of clear statutory intent to subsidize the coverage; (2) the government's insurance commitment may extend over multiple time

69. See SophiE M. KorCZyK, NAT'L Ass'N OF Mut. Ins. Co., InSURING THE UNINSURABLE: PRIVATE INSURANCE MARKETS AND GOVERNMENT INTERVENTION IN CASES OF EXTREME RISK 1-2 (2005). 
periods, allowing the government to recoup past losses through future premiums or other revenues; (3) the government may have a unique capacity to mitigate risks, for example by enforcing floodplain management standards or conducting financial examinations of insured financial institutions; (4) the government may provide backup coverage financed through general government revenues rather than premiums paid by the insured; and (5) the government may act as a monopoly in the insurance market, giving rise to low-quality services with low prices, which may impede the provision of preventive incentives that should be embedded in good insurance policies. $^{70}$

A multi-layered insurance program, with the government acting as a reinsurer of last resort, has been proposed by Robert Litan ${ }^{71}$ and Professor Howard Kunreuther ${ }^{72}$ for insuring catastrophe losses in the United States.

The current schemes for terrorism insurance in France (GAREAT), Germany (Extremus), the UK (Pool Re), the Netherlands (Dutch Terrorism Risk Reinsurance Company (NHT)), and the United States (Terrorism Risk Insurance Act (TRIA)) all have features of governments acting as a reinsurer of last resort. ${ }^{73}$

Pool Re provides an example in the U.K.:

The British government created Pool Re as a reinsurer of last resort in 1993 after private reinsurers reduced their coverage for risks from terrorism following bombings by the Irish Republican Army (IRA). With Pool Re, which is mutually owned by participating insurers, primary insurers may reinsure their risks from terrorism for commercial property losses and losses from business interruption. . . Pool Re sets premiums on the basis of the amount of insurance coverage, geographic location, and other risk factors.

70. But see infra Part II.C (showing how insurance provided by a state monopoly is not bad under some circumstances).

71. Robert E. Litan, Brookings Inst., POLICY Brief \#150: PrePARING FOR FUtUre "KATRINAS" 6-7 (2006) (proposing a federal office that formally insures citizens for mega catastrophes).

72. Howard Kunreuther, Has the Time Come for Comprehensive Natural Disaster Insurance? in ON RISK AND DISASTER: LESSONS FROM HURRICANE KATRINA 175, 196 (Ronald J. Daniels et al. eds., 2006); Howard Kunreuther \& Mark Pauly, Rules Rather than Discretion: Lessons from Hurricane Katrina, 33 J. RISK \& UNCERTAINTY 101, 109-13 (2006).

73. Michael Faure \& Klaus Heine, Insurance of Financial Crisis: The Way FORWARD, proposal submitted to 29th Annual Conference of the European Association for Law and Economics (Sept. 2012) (citing DWIGHT M. JAFFEE, DIRECTORATE FOR FINANCIAL AND ENTERPRISE AFFAIRS, REPORT ON THE ROLE OF GOVERNMENT IN THE COVERAGE OF TERRORISM RISKS 26-31 (2004)). 
However, primary insurers are free to set the price of terrorism coverage they offer. ${ }^{74}$ Pool Re must reinsure all offered policies; coverage begins after primary insurers pay roughly the first $\$ 150,000$ in claims. ${ }^{75}$ In turn, the British government reinsures Pool $\mathrm{Re}$ and agrees to guarantee any loans or lines of credit that the pool might seek. " ${ }^{76}$ "Once the pool's reserves exceed $\$ 1.5$ billion, it will pay to the government the greater of 10 percent of the net premiums remitted each year or a payment geared to the government's past losses." Because the system has been self-supporting, the state has never had to intervene as a reinsurer of last resort. ${ }^{78}$

\section{F. Government Simply Providing an Additional Insurance Layer}

Under another approach, the government finances catastrophic damages through an additional insurance layer, outside of the insurance market and on an ex post level, above the insurers' own financing. This scheme aims to supplement compensation from insurers (if needed) and thus to maximize the protection of victims in case damages exceed certain limits. ${ }^{79}$ Thus, under this approach the state merely guarantees an additional layer of compensation and does little to facilitate insurability. ${ }^{80}$

The nuclear liability conventions of the 1960s provided for a multi-layered compensation system. ${ }^{81}$ The first layer of the compensation is payable by the licensee of the nuclear power plant responsible for the incident (and covered by its insurance), the second, much larger, layer is provided by the state, and the third layer is provided by all the contracting parties. "The rights of victims of a nuclear accident to be compensated for losses are governed by

74. Cong. Budget OfF., Federal ReInsurance FOR DisASTERS 50 (2002), available at http://www.cbo.gov/sites/default/files/cbofiles/ftpdocs/37xx/doc3787/09-20-

federalreinsurance.pdf.

75. Id.

76. Id.

77. Id.

78. See id.

79. BRUGGEMAN, supra note 8 , at 203.

80. Id.

81. Michael G. Faure, Insurability of Damage Caused by Climate Change: A Commentary, 155 PENN. L. REV. 1875, 1886 (2007).

82. Id. 
international conventions, ${ }^{83}$ such as the Convention of Paris of July 29, 1960, the Convention of Brussels of January 31, 1963, and the Vienna Convention on civil liability for nuclear damages of May 21, $1963 .{ }^{84}$ "The conventions make the licensee of a nuclear plant strictly liable and introduce compulsory insurance. However, the maximum amount of compensation is limited, and short statutes of limitations apply." ${ }^{\prime 5}$ The conventions state that the signatory nations should provide for minimum compensation to victims, but, within the limits set by the convention, the nations are free to set the maximum amount of compensation. ${ }^{86}$ This regime has been changed by a protocol of 2004 which has, however, not yet entered into force. ${ }^{87}$

\section{G. New Forms of Government Intervention ${ }^{88}$}

Responsible governments aim to offer financial compensation in case insurance and reinsurance markets suffer from surplus depletion following a catastrophic event. As discussed above, the government can act, inter alia, as a primary insurer or as a reinsurer of last resort. The latter role can be further limited to losses that exceed some threshold of insurance industry losses. The government thereby auctions excess-of-loss (XOL) contracts to insurers and reinsurers. The government can also act as a lender of last resort.

83. Michael Faure, Economic Models of Compensation for Damage Caused by Nuclear Accidents: Some Lessons for the Revision of the Paris and Vienna Conventions, 2 EURO. J. LAW \& ECON. 21, 21 (1995).

84. See id. at 24-25.

85. Id. at 21.

86. See generally id. (arguing that a mutual pooling system, whereby all nuclear plants share the costs of an accident, could be fitted into a revision of the Paris and Vienna Conventions on liability for nuclear accidents); Michael Faure \& Tom Vanden Borre, Compensating Nuclear Damage: A Comparative Economic Analysis of the U.S. and International Liability Schemes, 33 WM. \& MARY ENVTL. LAW \& POL'Y REV. 220, 220-86 (2008) (comparing the evolution of the American nuclear compensation scheme under the Price-Anderson Act to international compensation schemes); Göran Skogh, A European Nuclear Accident Pool, 33 THE GENEVA PAPERS 274, 274-87 (2008) (explaining how compensation to victims would be better organized by an organization like the European Union, which could hold states strictly liable, as opposed to the current system where compensation is based on the OECD Paris Convention and the UN Vienna Convention and where a plant is strictly liable but victims are left without compensation if the plant is insolvent).

87. See Nuclear Energy Agency, Paris Convention on Nuclear Third Party Liability, OECD NUCLEAR ENERGY AGENCY, http://www.oecd-nea.org/law/paris-conventionratification.html (showing the latest status of ratifications or accessions).

88. Parts I.G, I.G.1, and I.G.2 borrow from a book written by one of the authors, see BRUGGEMAN, supra note 8 , at 190-92, 205-06. To ease readability, quotation marks have been omitted. 


\section{Federal Excess-of-Loss Reinsurance Contracts}

Economist Christopher Lewis and Professor Kevin Murdock propose a form of federal reinsurance that complements existing insurance and reinsurance products, focuses on diversifying large disaster losses over time, and also limits the federal government's exposure to additional losses. ${ }^{89}$ Specifically, the federal government would sell per-occurrence XOL contracts to private insurers and reinsurers, in which both the coverage layer and the fixed payout of the contract would be based on aggregate insurance-industry losses, and not on company-specific losses. These XOL contracts would be available for qualified insurance companies, pools, and reinsurers, and would cover industry losses in the twenty-five to fifty billion dollar layer of coverage-or any layer unavailable in the private market. Lewis and Murdock further suggest for these auctions to be conducted subject to a reservation price sufficient to support the expected loss and expense costs under the contracts as well as to include a risk premium that would encourage private-market crowding-out of government reinsurance. If a catastrophe occurred that would trigger payment under the contracts, the federal government would finance the loss payments by issuing bonds.

The rationale for government provision of these contracts is that the capacity of private insurance and reinsurance markets is currently inadequate to provide coverage for losses of this magnitude. The government has a superior ability to diversify risks across time through the exercise of federal borrowing power. While it is costly for private insurers to raise additional capital following a loss shock, federal debt is viewed as more secure and thus the government would not find its cost of capital increasing significantly in the wake of a catastrophe. The proposed XOL contracts would help to solve the problems in insurance markets while potentially reducing the federal government's role in providing disaster relief payments to property owners following a catastrophe. The contracts do not provide a subsidy to insurers but instead are designed to be self-supporting in terms of expected value - that is, the contracts are to be priced so that the expected cost to the government is zero.

89. Christopher M. Lewis \& Kevin C. Murdock, The Role of Government Contracts in Discretionary Reinsurance Markets for Natural Disasters, 63 J. RISK \& INSURANCE 567, 567 (1996); David Cummins, Christopher M. Lewis, \& Richard D. Phillips, Pricing Excess-of-Loss Reinsurance Contracts against Catastrophic Loss, in THE FINANCING OF CATASTROPHIC RISK 93 (Kenneth A. Froot ed., 1999). 
Both authors argue that this form of limited per-occurrence XOL contract is the preferred reinsurance mechanism for the government because it would expand the capacity and stability of the catastrophe insurance industry, while limiting the taxpayers' exposure to the insured catastrophic event. Furthermore, a targeted and risk-specific government reinsurance program has the advantage of supplying reinsurance without imposing large liability on the government. Moreover, by offering a complementary reinsurance vehicle that does not compete with the private sector, efficient coverage can be provided to the private insurance markets whenever feasible. Further advantages include that the federal government may carry less of an insolvency risk and that the risk premiums required by the government reinsurer for upper layers of catastrophe risk will be significantly below the premiums required by private reinsurers. The key advantage of the auction device is that the private insurance firms play a major role in determining the price they must pay to obtain the government's reinsurance contract, in contrast to the existing options in which the price is administratively determined by the government.

A potential drawback of the auctioning of XOL reinsurance contracts "may be in the details, since the government must determine all of the auction conditions, including how much aggregate coverage to offer, and the conditions under which new 'tranche' will be available, if at all, in the future. Additionally, since the contracts would most likely include triggers and payouts based on industry-wide losses, individual firms would face basis risk." ${ }^{\text {90 }}$

\section{Government as Lender of Last Resort}

Professors Dwight Jaffee and Thomas Russell have proposed the introduction of a temporary loan scheme for catastrophe insurers. ${ }^{91}$ They argue that the financial system is no stranger to a program of temporary government loans. Central banks, for example, have (at least if one disregards the recent financial crisis) long guaranteed the stability of the commercial banking system by acting as temporary "lenders of last resort." (Of course, there are differences between banks and the government, but the authors argue that these are one

90. See JAFFEE, supra note 18, at 37-38.

91. DWight JAFFeE \& THOMAS RUSSEll, APRIA, FinANCing CATASTROPHE Insurance: A New Proposal 6-7 (2006); Dwight JAFFEe \& ThOMAS Russell, NBER INSURANCE PROJECT WORKSHOP, EXTREME EVENTS AND THE MARKET FOR TERRORIST InsurAnCE 24-25 (2002); Dwight Jaffee \& Thomas Russell, Should Governments Provide Catastrophe Insurance?, 3 ECONOMISTS' VOICE 1, 4-6 (2006). 
of degree and not of kind.) Suppose, then, that public policy makers decide to extend the lender-of-last-resort function to providers of catastrophe insurance. As an insurance company which has just paid out a large claim does not have the quantity or quality of assets of a solvent bank, the public lending agency will need to offer unsecured loans. This, in turn, will require that the public lender be the leading creditor in the event of a bankruptcy. Under this approach, taxpayers will bear credit risk, but this risk is likely to be smaller than the risk they would bear if the government were to itself provide direct insurance or reinsurance.

The purpose of such loans is to provide insurers with time to access equity capital markets. Thus, the loans must be of short duration, two to three years at maximum. Moreover, as the loans are intended to overcome the problem of non-availability of capital, there is no need to subsidize insurers, and the loans should be offered at market price. Also, since the explicit purpose of the loans is to temporarily provide policy-writing capacity, the borrowing insurance company should be explicitly required to raise equity capital and provide additional coverage during the loan period. The loan agreement could explicitly provide additional incentives for firms to do so, for example, by lowering the loan rate as the firms raise their equity bases.

\section{STIMULATING INSURABILITY: A NORMATIVE LAW-AND- ECONOMICS ANALYSIS}

Part I described the various ways in which government can and does intervene in compensating victims of catastrophes. In this part, we will provide a normative law-and-economics analysis of the various forms of government intervention and assess their economic efficiency. ${ }^{92}$ First, in Part II.A, we will show that many law-and-

92. The relatively modest form of government intervention in which the government merely supports the private market (through, for example, tax exemptions), see supra Part I.A., does not need further discussion for the simple reason that the government in such cases does not run any financial risk. The new forms of government intervention discussed in Part I.G will also not be discussed any further. These interesting models have been suggested in the literature, but they do not yet exist in practice and are therefore less appealing as subjects for further analysis. The role of the government in simply providing an additional risk layer, see supra Part I.F, will also not be discussed in more detail because government intervention in this case is not related to stimulating insurability. Instead, in such cases, the government merely provides supplementary compensation to the extent that the money provided as a result of the (limited) liability of the licensee of a nuclear power plant does not suffice to compensate the victims. In that respect, the government's role is comparable to providing direct compensation to victims of catastrophes-there is no relationship to insurance in either of the cases. 
economics scholars have described ex post relief as problematic. Second, in Part II.B, we will argue that introducing mandatory comprehensive insurance may be a better solution. Third, in Parts II.C and II.D, we will focus on the potential role for the government in insuring emerging catastrophe risks as a primary insurer and as a reinsurer of last resort.

\section{A. Direct Compensation to Victims of Catastrophes: Government as Santa Claus}

\section{Political Inefficiencies}

One way for the government to stimulate compensation for victims of catastrophes is to simply take over the compensation function and provide ex post relief to victims. As we described above ${ }^{93}$ this type of ex post relief can take different forms-it can consist of a disaster compensation fund ${ }^{94}$ or simply of ad hoc compensation whereby the government decides on the basis of the nature and scope of the disaster how much relief to provide. Usually, these forms of ex post relief provide lump-sum payments to victims and are financed by the taxpayers.

However, a distinction should be made between government intervention in the prevention of catastrophes-for example, by building dikes against flooding-which usually takes place ex ante, and a role of government in providing compensation, which takes place ex post.

A positive aspect of ex post government intervention is that "[t]he prospect of large-scale payouts in the aftermath of major losses might ... encourage the government to take cost-benefit justified precautions long before disaster strikes." ${ }^{95}$ This argument is particularly strong in the case of terrorism. The goal of terrorist attacks is often to disrupt society, and ex post relief may help restore

Government provision of an additional insurance layer is thus susceptible to roughly the same law-and-economics objections as the provision of direct compensation; the only difference is that when the government provides only an additional risk layer, at least some compensation is still provided by the liable insurer.

93. See supra Introduction

94. See, e.g., Dagmar \& Koch, supra note 24, at 7-12 (discussing the Kataztrophenfondsgesetz in Austria, an administrative fund with state aid contributions for catastrophe indemnification); Durant, supra note 25, at 38 (outlining the current patchwork system for compensation in Belgium, which includes government intervention).

95. See Saul Levmore \& Kyle D. Logue, Insuring Against Terrorism-and Crime, 102 MiCH. L. REV. 268, 310 (2003). 
the public trust. Moreover, terrorists may adopt adaptive strategies to which governments can potentially react better than individualsthere is little one can expect from civilians as far as taking preventive measures is concerned. The same is obviously true of large-scale infrastructural works that are necessary to prevent catastrophes. These are typically public goods that would not be provided through private action and may hence require government intervention.

Professor Ben Depoorter has argued that politicians may receive too little reward from ex ante disaster-management policies and that these policies may be undersupplied as a result. ${ }^{96}$ The problem is exacerbated because political benefits of planning activities may be shared with other levels of government. ${ }^{97}$ In contrast, the political reward for ex post compensation may be very strong, and ex post relief is thus likely to be oversupplied. ${ }^{98}$ This has also been confirmed in other literature. Public choice theory shows that governments will always tend to intervene when the number of victims is large. ${ }^{99}$ Potential victims are, after all, voters, and governments will try to seduce the largest number of electors in order to gain or maintain power. ${ }^{100}$ "A political [and strategic] interest might thus be hidden behind the argument of victim[] protection., ${ }^{101}$ Second, public choice theory also demonstrates that public intervention is costly. State organization of compensation financing-especially through public insurance pools - can be analogized to a bureaucracy. ${ }^{102}$ In that respect, Professor Gordon Tullock shows that this type of scheme might suffer from economic inefficiency. ${ }^{103}$ This inefficiency appears to be due to internal rent-seeking activities, and, in case of public

96. Ben Depoorter, Horizontal Political Externalities: The Supply And Demand of Disaster Management, 56 DUKE L.J. 101, 112-13 (2006).

97. Id. at 110 .

98. Id. at 104 (2006) (describing how this may have been the case after Hurricane Katrina).

99. See Louis Kaplow, Incentives and Government Relief for Risk, 4 J. RISK \& UNCERTAINTY 167, 171-73 (1991) (arguing that government relief for risk actually "distorts" incentives because it externalizes the cost of individual actions); see also Epstein, supra note 3, at 293-96 (saying that, while viewed ex post the marginal dollar spent in relief after a catastrophe has greater value to the recipients than it does to the tax-payers, viewed ex ante such relief is less clearly efficient); Role for Government, supra note 4, at 49-50 (discussing the crises with private insurance in the United States following the 2001 terrorist attacks).

100. BRUGGEMAN, supra note 8, at 198.

101. Id.

102. Id.

103. Gordon Tullock, The Welfare Costs of Tariffs, Monopolies, and Theft, 5 W. ECON. J. 224, 230 (1967). 
insurance pools, due to capture of a monopolistic profit. ${ }^{104}$ Indeed, economist Thomas Gerrett and Professor Russell Sobel showed that disaster expenditures by FEMA are mostly politically motivated: "[s]tates [that are] politically important to the president have a higher rate of disaster declaration by the president, and disaster expenditures are higher in states having congressional representation on FEMA oversight committees." ${ }^{, 105}$ Hence, Gerrett and Sobel argue that "nearly half of all disaster relief is motivated politically rather than by need." 106

An additional problem arises when government compensation is provided for victims of technological disasters-the compensation favors not only the victims but also the injurers. Indeed, since governments pay for the consequences of the risk generated by the injurers, the injurers are relieved from the compensation charge. This discharge corresponds to exoneration, thus creating a double inefficiency. On the one hand, since injurers do not have to pay compensation (partly or fully), government intervention has a subsidizing character. This implicit subsidy might disturb the injurers' incentives to care. Professors Karine Fiore and Michael Faure illustrate this argument for the nuclear industry in France (and elsewhere in Europe), where the state pays for a large share of compensation in case of an accident ${ }^{107}$ Of course, this problem does not arise in the case of natural catastrophes or terrorist activities, where no solvent injurer can be identified.

\section{Incentive Problems}

This part lists additional problems-other than the inefficiencies discussed above-that law-and-economics scholars have identified with respect to government provision of ex post relief to disaster victims.

104. Obviously, the severity of the criticisms partially depends upon the nature of the arrangement. To the extent that government relief can be structured to still provide some incentives to the victims (for example, by including deductibles or by differentiating the amount of compensation based on preventive measures taken by the victim) and that financing can to some extent still be risk-based (although that is seldom the case), the criticisms may be less serious.

105. Thomas A. Garrett \& Russell S. Sobel, The Political Economy of FEMA Disaster Payments, 41 ECON. INQUIRY 496, 496 (2003).

106. Id.

107. Michael G. Faure \& Karine Fiore, An Economic Analysis of the Nuclear Liability Subsidy, 26 PACE ENVTL. L. REV. 419, 432-36 (2009). 
First, since lump-sum government-relief payments usually do not relate to risk, no incentives are provided to potential victims to take effective preventive measures. Of course, whether it is realistic for the victims to take preventive measures will very much depend upon the nature of the disaster. Preventive measures that require a significant ex ante investment of infrastructure will, for the public-good reason discussed above, be primarily undertaken by government. For example, taking structural measures to protect a country against tsunamis or against terrorism risk is primarily a government task. Individual potential victims can certainly take some protective measures, not so much to prevent a disaster, but rather to limit the damage it may cause. For example, flood damage can obviously be prevented by not locating buildings in flood-prone areas. Nevertheless, the government may be best situated to know the location of these flood-prone areas and may use zoning regulations to limit construction in those areas. Additionally, even when exposed to flood risks, victims can still take preventive measures-for example, in the case of flooding, by removing the most valuable household objects from the cellar or ground floor. These measures may be relatively limited compared to the impact of infrastructural works that the government could undertake, but they remain important. The problem-also called the "charity hazard" by Paul Raschky and Professor Hannelore Weck-Hannemann ${ }^{108}$ and as defined by Professors Mark Browne and Robert Hoyt ${ }^{109}$-is that ex post relief by the government will not provide incentives to take those appropriate preventive measures. The literature thus suggests that, via risk differentiation, competitive insurance markets are better able to deal with moral hazard and adverse selection. ${ }^{110}$

A second problem is that victims may be counting on government compensation, which may create an incentive not to

108. See Paul A. Raschky \& Hannelore Weck-Hannemann, Charity Hazard-A Real Hazard to Natural Disaster Insurance, 7 NAT. HAZARDS 321, 322 (2007).

109. See id. at 322; see also Mark J. Browne \& Robert E. Hoyt, The Demand for Flood Insurance: Empirical Evidence, 20 J. RISK \& UNCERTAINTY 291, 293 (2000) (defining charity hazard as "the tendency of an individual at risk not to procure insurance or other risk financing as a result of a reliance on expected charity from others such as friends, family, community, nonprofit organizations, or a government emergency program"); Tracy Lewis \& David Nickerson, Self-Insurance Against Natural Disasters, 16 J. ENVTL. ECON. \& MGMT. 209, 209-10 (1989).

110. George L. Priest, The Government, the Market, and the Problem of Catastrophic Loss, 12 J. RISK \& UNCERTAINTY 219, 222 (1996). 
purchase insurance, since victims can simply free-ride on the State. ${ }^{111}$ In the words of Professor Christian Gollier, "[s]olidarity kills market insurance." 112 Stephen Coate has linked the lack of insurance to the generosity of the government. ${ }^{113}$ An experimental study of crop insurance in the Netherlands also showed that the willingness of producers to purchase private insurance (supported by the government) was significantly negatively influenced by their belief about the availability of government-supplied disaster relief in the future. ${ }^{114} \mathrm{~A}$ similar conclusion was also recently reached based on empirical research comparing compensation mechanisms available in different countries after the August 2005 flood in Austria, Switzerland, and the German state of Bavaria. ${ }^{115}$ The study argues that there was a substantial charity hazard leading to lower amounts of insurance purchased in Austria, where a disaster fund was available. ${ }^{116}$ Participation in flood insurance was higher in Bavaria, although it was the highest in the Swiss canton of Grison, which had public insurance and mandatory participation. ${ }^{117}$

Negative distributional effects are a related problem, as some victims - who, for example, purchased houses at low prices in floodprone areas-may free-ride on other individuals (the general taxpayers) who finance the ex post relief. ${ }^{118}$

Ex post government compensation is therefore generally seen as problematic by law-and-economics scholars. This criticism is nicely expressed by the title of a work by Professor Richard Epstein, which characterizes ex post relief as "Catastrophic Responses to

111. See, e.g., Levmore \& Logue, supra note 95, at 281; see also Kaplow, supra note 99, at 167, 173 (exploring the notion that government relief may have an adverse effect on private incentives to purchase insurance).

112. BRuggeman, supra note 8, at 207 (citing Christian Gollier, Some Aspects of the Economics of Catastrophe Risk Insurance, CATASTROPHIC RISKS \& INSURANCE 13, 25 (2005)).

113. Stephen Coate, Altruism, the Samaritan's Dilemma and Government Transfer Policy, 85 AM. ECON. REV. 46, 46 (1995).

114. See Marcel A.P.M. van Asseldonk, Miranda P.M. Meuwissen \& Ruud B.M. Huirne, Belief in Disaster Relief and the Demand for a Public-Private Insurance Programme, 24 REV. AGRIC. ECON 196 (2002) (discussing how free government relief in the past disincentivized farmers in the Dutch crop insurance program).

115. See Paul A. Raschky et al., Risikotransfersysteme für Naturkatastrophen in Deutschland, Österreich und der Schweiz-Ein theoretischer und empirischer Vergleich, 77 VIERTELJAHRSHEFTE ZUR WIRTSCHAFTSFORSCHUNG 53 (2008) (comparing "risk transfer," or insurance, systems in Germany, Austria, and Switzerland after they were affected by floods in 2005).

116. Id. at 66-67.

117. Id.

118. BRUGGEMAN, supra note 8, at 207. 
Catastrophic Risks."119 Weighing these disadvantages against the potential benefits of such an approach-that is, providing incentives to the government to take measures aimed at the prevention of disasters - the disadvantages seem to be overwhelming. It is not clear to what extent the payment of ex post relief effectively incentivizes the government to take preventive measures. ${ }^{120}$ Moreover, as Professor Depoorter has recently showed, the prospect of having to pay ex post relief in the future apparently does not encourage politicians to invest in disaster-prevention mechanisms for the simple reason that the political benefits of the two are different, which results in an oversupply of ex post relief and undersupply of disaster preparation measures. ${ }^{121}$

However, as we have shown above, notwithstanding the many arguments against ex post relief, in practice governments in many legal systems cannot resist the temptation to provide generous amounts of $a d$ hoc or structural relief after disasters have occurred. ${ }^{122}$ As described above, ex post relief may provide large political benefits to politicians. Professor Jack Hirschleifer has stated that providing compensation after the occurrence of a disaster is so politically attractive that the government will invariably find it impossible to resist payment, ${ }^{123}$ and this point has been echoed by others. ${ }^{124}$ As a result, in many countries the compensation for victims of catastrophes is a topic of discussion and legal reform. ${ }^{125}$ One of the issues addressed is whether the government can play a role that is less distortive and provides better incentives for prevention.

119. Epstein, supra note 3, at 297-98.

120. BRUGGEMAN, supra note 8, at 208.

121. See Depoorter, supra note 98 , at 103-04.

122. See, e.g., Monti \& Chiaves, supra note 46, at 169 ("[E]very year the Italian Government spends on average 3.5 to 4 billion euros to indemnify damages caused by catastrophic events.").

123. See Hirshleifer, supra note 51, at 146-47 ("In the author's opinion, in the absence of an insurance program, it will be politically impossible for the government not to compensate for damage.").

124. See Peter Siegelman, A New Old Look at Terrorism Insurance: Jack Hirschleifer's War Damage Insurance After 50 Years, 9 CONN. INS. L.J. 19, 24 (2002).

125. See, e.g., Véronique Bruggeman et al., The Government as Reinsurer of Catastrophe Risks?, 35 THE GENEVA PAPERS 369, 369-83 (2010); FAURE \& HARTLIEF, supra note 30, at 12. 


\section{B. Mandatory Comprehensive Insurance: An Attractive Solution}

One possible government intervention to facilitate the provision of catastrophe insurance-in particular to stimulate the demand for this type of insurance-is to make insurance mandatory. While such compulsory insurance does not go totally undisputed (especially in cases where it would also force individuals who run no risk at all ${ }^{126}$ to purchase insurance coverage), there seems to be support for such a regulatory policy in law-and-economics scholarship.

Many scholars-particularly Professor Kunreuther-have argued in favor of compulsory first-party (in other words, bought by potential victims) insurance for property damage caused by all kinds of natural disasters. ${ }^{128}$ This model, whereby the duty to insure against disasters is combined with insurance against a high-probability, low-damage event, is also supported by behavioral literature. ${ }^{129}$ Further, compulsory insurance is thought to play an important role in improving hazard perception. ${ }^{130}$

Professor Kip Viscusi has recently supported the idea of mandatory disaster insurance. He defends this approach based on the assumption that politicians are unable to deny post-disaster aid. ${ }^{131}$ Comprehensive insurance may be an attractive alternative, ${ }^{132}$ which would at least foster self-protection and insurance. ${ }^{133}$

However, even if the lack of demand for disaster insurance could be solved by mandating the purchase of insurance, problems can also

126. For example, an owner of a tenth-floor apartment has hardly any risk of suffering flood damage.

127. Mandatory disaster insurance is not the central focus of this paper. For more details, see generally Faure \& Bruggeman, supra note 6; see also Levmore \& Logue, supra note 95, at 304.

128. See generally Howard Kunreuther, The Case for Comprehensive Disaster Insurance, 11 J.L. \& ECON. 133, 142-63 (1968).

129. See id. at 159-60 (discussing how, in this system, the isolated homeowner without insurance "would simply be considered a gambler who lost").

130. Id.

131. W. Kip Viscusi, The Hold-Up Problem: Why it is Urgent to Rethink the Economics of Disaster Insurance Protection, in THE IRRATIONAL ECONOMIST: MAKING DECISIONS IN A DANGEROUS WORLD 142, 142-48 (Erwann Michel-Kerjan \& Paul Slovic eds., 2010) ("Saying that one will not support assistance after a future hurricane may, of course, be a form of hypothetical trash talk. It is a very different matter to actually deny assistance once there are identified victims and their stories are featured on the evening news.").

132. Howard Kunreuther \& Mark Pauly, Insurance Decision-Making and Market Behaviour, 1 FOUNDATIONS \& TRENDS IN MiCROECONOMICS 63, 117 (2005).

133. See Viscusi, supra note 131, at 146-48 (offering policies to foster self-protection and insurance). 
arise on the supply side, especially given the "difficult-to-predict" nature of catastrophes. ${ }^{134}$ As pointed out in Part I, the Solvency II Directive admittedly mitigates the problem of insolvency of the insurer, but a risk remains that there will not be sufficient resources. Hence, a question arises: What is the government's role when the amount of damage caused by a disaster is higher than normal insurance coverage? As we argued above, any alternative is better than providing direct compensation to disaster victims. One possibility, discussed in Part II.C, is to have the government act as the primary insurer; another, discussed in Part II.D, is to have the government serve as a reinsurer of last resort.

\section{Government Acting as the Primary Insurer: The Case of Efficient Monopolies}

The increasing dissatisfaction with outright ex post relief combined with the feeling that catastrophic losses may be so large that traditional insurance markets may not be able to provide full coverage has led to the development of new structures. On the one hand, insurance markets would be used to the extent possible and, on the other hand, the government would intervene to support insurance markets when the markets fail. ${ }^{135}$

These kinds of structures are increasingly welcomed by law-andeconomics scholars. We will now look at these types of government intervention in a more integrative way. First, we will address the role of the government as primary insurer. Initially, this approach only seems effective in cases where insurance markets would not emerge. However, various scholars have stressed that under particular circumstances, government monopolies for disaster insurance may in fact provide coverage at lower prices than the competitive market.

\section{The Swiss Example}

In Switzerland, home insurance has developed along two lines. In nineteen of the twenty-six cantons, insurance is offered by a regional monopoly and is compulsory. ${ }^{136}$ Homeowners are obliged to buy

134. For a more detailed analysis of problems on the supply side, see Christian Gollier, Some Aspects of Economics of Catastrophe Risk Insurance, in CATASTROPHE RISKS AND INSURANCE 13-30 (OECD Publishing 2006); see also FROOT, supra note 7.

135. The Geneva Ass'N, Risk \& Insurance ECONOMICS, ANNUAL REPORT 2011/2012 49 (2012).

136. Thomas von Ungern-Sternberg, The Limits Of Competition: Housing Insurance in Switzerland, 40 EUR. ECON. REV. 1111, 1113-14 (1996). 
housing insurance against fire and natural disasters. ${ }^{137}$ However, the insurance covers only these two types of damages and does not extend to acts of terrorism. ${ }^{138}$ In the remaining seven cantons, insurance is not offered by public monopolies, but by the private market. ${ }^{139}$ This dichotomy allows us to compare two different approaches to home insurance within a single country.

The Swiss example is of course an exception rather than the rule. Nevertheless, the general finding is quite striking-namely, in the cantons where insurance is offered by state monopolies, the premium rates are lower than the rates in cantons with private insurance..$^{140}$ The following diagram compares premium prices of cantonal and private insurers between 1984 and 1995 and also provides an overview of the different components of the premiums.

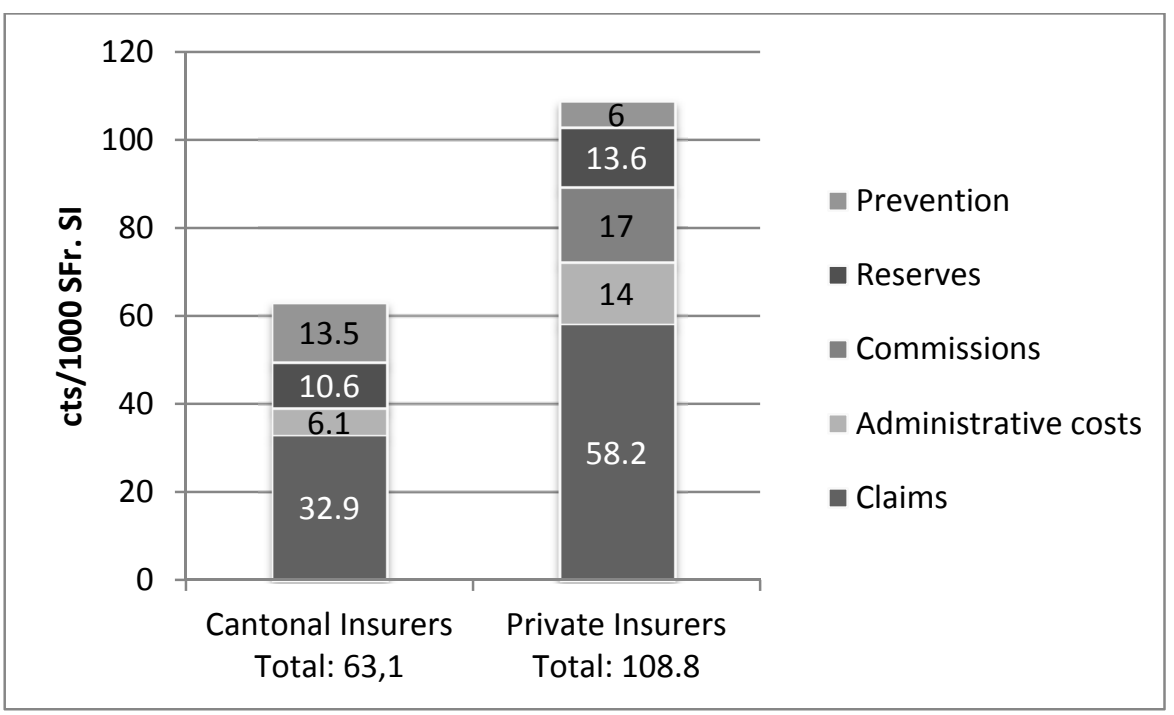

Fig. 1. Premium Rates Comparison (Fire and natural disasters, 1984-1995) ${ }^{141}$

This overview shows that, especially with regard to administrative costs and commissions, there is a huge discrepancy

137. Id.

138. See id. (discussing the role compulsory state-supplied insurance plays in housing and natural damage insurance markets).

139. Id.

140. Id. at $1114-16$.

141. Mario Jametti \& Thomas von Ungern-Sternberg, Assessing the Efficiency of an Insurance Provider-A Measurement Error Approach, 30 GENEVA RISK \& INS. REV. 15, 18 (2005). 
between the two types of insurers. While the private insurers spend thirty-one cents per 1000 square feet of housing stock insured for commissions and administrative costs, the cantonal insurers spend less than one-fifth of this amount for the same items. This difference can be explained by the costs faced by private insurers to manage their network of sales agents. ${ }^{142}$ Since insurance is offered by a multitude of insurers, sales agents may have difficulties getting new customers. Commissions paid to the sales agents can serve as a motivation for these representatives to sell more insurance. These commissions for sales representatives of course do not need to be paid by state monopolies providing compulsory insurance. ${ }^{143}$ Admittedly, a potential downside of the system is that the state monopoly has no real incentives to keep costs low. However, as shown in the diagram above, insurance is still cheaper in cantons where insurance is not offered on the private market.

Administrative costs alone do not explain the difference in premium rates between government-monopoly and private-market cantons-as shown in the diagram above, the damage rates also differ to a significant extent. Contrary to commentary from the private insurance sector, this difference cannot be explained solely by exogenous factors. Damage rates may still differ in cantons which are sufficiently homogeneous based on geographic proximity and housing structure similarity-such as Geneva and Lausanne. ${ }^{144}$ In this example, damage rates in Lausanne are only half as high as in Geneva. ${ }^{145}$ In the latter canton, there is no government supplier, whereas in Lausanne insurance is provided by a cantonal monopoly. ${ }^{146}$ This difference in damage rates has to be taken together with the higher amount spent by the cantonal insurers on prevention. This provides for a real-life application of the Coase Theorem ${ }^{147}$-in the cantons where insurance is provided by state monopolies, higher amounts are spent on prevention, which is mirrored in lower damage rates. $^{148}$

142. See von Ungern-Sternberg, supra note 139, at 1116 (discussing the lower administrative costs).

143. See id., supra note 139 , at 1117.

144. Id. at 1116 .

145. Id.

146. Id.

147. According to the Coase Theorem, trading in externalities between different bargaining parties will, in the absence of transaction costs, lead to an efficient outcome, regardless of the initial allocation of property rights.

148. Id. at 1116. 
Another observation that explains both the incentives for better prevention and the advantages of a public monopoly in this sector has been brought forward by Professor Winand Emons. Professor Emons highlights the importance of certain requirements that must be met in order for a house to be insured. ${ }^{149}$ Compliance with the requirements is monitored by insurance companies. ${ }^{150}$ Because insurance is provided by one public monopoly, the result of such testing is rather straightforward: either the house passes the test and insurance is acquired, or the homeowner must make changes to the house to fulfill the required standard. ${ }^{151}$ In contrast, in the case of multiple insurers, the homeowner might be tempted to try to obtain insurance from another company instead of trying to bring his house up to the required standard set by the first insurer. ${ }^{152}$ This leads to a decrease in prevention costs and eventually to an inefficient market. ${ }^{153}$

The Swiss case has been accepted almost unequivocally as an example of regional monopolies that operate more efficiently than the private sector. The authors have been able to identify only one scholar, Professor Bernd Schips, who has brought forward an opposing analysis. ${ }^{154}$ Schips explains that the problem with the cantonal monopolies in Switzerland is that political choices do not always reflect economic efficiency criteria. ${ }^{155} \mathrm{He}$ is afraid that the cantonal monopolies are structured according to criteria that serve the political interests of the respective parties and not according to efficient objective criteria. ${ }^{156} \mathrm{In}$ his calculation, it is actually the private insurers and not the monopolies that offer better prices. ${ }^{157}$ Rejecting Professor Thomas von Ungern-Sternberg's analysis, Schips concludes that the cantonal monopolies are not in an exceptional position and cannot be regarded as operating more efficiently than the private

149. See Winand Emons, Imperfect Tests and Natural Insurance Monopolies, 49 J. INDUS. ECON. 247, 251-55 (2001) (discussing the requirments used to test insurability).

150. Id. at 252 .

151. See id. at 253 (analyzing actions a homeowner can take to qualify for insurance coverage).

152. See id. at $255-57$ (introducing competition into the analysis).

153. Id. at 249-50.

154. Bernd Schips, Ökonomische Argumente für wirksamen Wettbewerb auch im Versicherungszweig 'Gebäudefeuer- und Gebäudeelementarschäden (1995) (unpublished manuscript) (on file with ETH Zuerich).

155. Id.

156. Id.

157. Id. 
insurers. ${ }^{158}$ The difference between these analyses, however, can be sufficiently explained by the application of different statistical methods. ${ }^{159}$ Given that there is not one paper that supports Schips' analysis, the Swiss example can indeed be accepted as a case of efficient monopolies. ${ }^{160}$

2. A German Example: The Third Non-Life Insurance Directive and its Influence on the Insurance Market in Baden-Württemberg

That home insurance in the majority of the Swiss cantons is still provided by regional monopolies is also due to the fact that Switzerland is still not a member of the European Union. The drive for liberalization and privatization within the European Union would certainly have made it difficult to uphold this system. ${ }^{161}$ For example, in Germany, the introduction of the Third Non-Life Insurance Directive $^{162}$ ended the life of several existing state insurance monopolies. The transition to market competition in the home insurance sector in Baden-Württemberg nicely illustrates the downsides of this shift. Because the demonopolization led to a huge increase in premiums, the Baden-Württemberg example fits well into the lessons learned from the Swiss case. ${ }^{163}$ Karl Epple and Reinhard Schäfer have also identified similarities between the two cases with regard to the calculation of premium rates, and pointed out that the state insurer need not pay for advertising and sales representatives. ${ }^{164}$

\section{Efficient Monopolies - Delineating Key Factors}

Having given two examples in which state monopolies seem to be more efficient in the insurance sector than private insurers, this part identifies the underlying core variables. The experiences in Switzerland and Germany will be used to outline some conditions under which government insurance may enhance welfare.

158. Id.

159. See id. at 31; see also Gebhard Kirchgässner, On the Efficiency of a Public Insurance Monopoly: The Case of Housing Insurance in Switzerland, in PUBLIC ECONOMICS AND PUBLIC CHOICE 221, 226 (Pio Baake \& Rainald Borck, eds., 2007).

160. See Kirchgässner, supra note 159 , at 226.

161. Id. at 224 .

162. Council Directive 92/49/EEC, 1992 O.J. (L 228/1) (EC) (directing EC countries to end state non-life insurance policies to provide for a freer market).

163. See Karl Epple \& Reinhard Schäfer, The Transition from Monopoly to Competition: The Case of Housing Insurance in Baden-Württemberg, 40 EUR. ECON. REV. 1123, 1129-31 (1996).

164. See id. at 1129. 
i. The Compulsory Nature of Insurance Provided by State Monopolies-Comprehensive Coverage and Adverse Selection

As stated above, in the nineteen cantons in Switzerland where insurance is provided by regional monopolies, being insured is compulsory. Combined with the fact that there will only be one insurer from whom the customer can buy insurance, this has two major advantages. First, it prevents adverse selection. A major challenge faced by insurance companies is to avoid ending up with only the bad risks after the good ones leave the pool. Where a state monopoly provides compulsory insurance, automatic risk diversification takes place. ${ }^{165}$ This successfully fights the problem of adverse selection. In contrast, a regional monopoly offering compulsory insurance is better able to offer more comprehensive coverage-it can cover risks such as flooding or earthquakes. ${ }^{166}$

\section{ii. The Role of Prevention}

The special role that prevention plays under the regime offered by the cantonal insurers in Switzerland has already been discussed above. Prevention will reduce claims, enabling the insurers to keep premiums low. ${ }^{167}$ It is an absolute prerequisite that the insurer plays an active role in preventive measures. ${ }^{168}$ This is one of the main lessons from the Swiss example. By being actively in charge of organizing and financing prevention efforts, the cantons have found an original solution to the problem of prevention. ${ }^{169}$ The Swiss model seems to work because the cantons are liable for damage payments as insurers, and the model provides the cantons with incentives to use their public powers to require preventive efforts. Of course, preventive efforts are also required from individual insured homeowners. Compared to a private market with multiple insurers, cantonal monopolies are thereby in a better position to enforce preventive efforts. ${ }^{170}$

The importance of active involvement is further demonstrated in Germany. Despite investing huge amounts in prevention, the monopolies never played an active role in preventive measures. Von

165. Id. at 1127.

166. See id. at 1125.

167. See von Ungern-Sternberg, supra note 139, at 1116.

168. Id. at 1117 .

169. ThOMAs VON Ungern-Sternberg, EFficient MONOPOlies - The Limits of COMPETITION IN THE EUROPEAN PROPERTY INSURANCE MARKET 106 (2004).

170. See Emons, supra note 153, at 248-49. 
Ungern-Sternberg cites this inactivity as one of the reasons that the state monopolies in Germany did not survive. ${ }^{171}$

\section{iii. Non-Profit Organization}

The form of the institution providing insurance is also relevant for a system of efficient state monopolies. Specifically, insurers must be non-profit organizations. ${ }^{172}$ Non-profits are not required to generate or distribute revenue. The non-distribution constraint allows them to keep sufficient capital reserves while also keeping premium rates low.

\section{iv. Yardstick Competition}

Finally, regional monopolies will only provide insurance coverage in an efficient way if competition between different monopolies still exists. This sounds contradictory. However, within Switzerland there is a form of competition between the different cantonal monopolies. This form of yardstick competition should not be regarded as competition in stricto sensu but should be understood as a means of comparison between the various regional monopolies and the services they offer. This has positive effects on innovation and efficiency because one regional monopoly can adapt based on the decisions of another regional monopoly. Having only one state monopoly would destroy this advantage and make the system unworkable. ${ }^{173}$

\section{Government as a Reinsurer of Last Resort}

In this particular case, government intervention is geared towards supporting the traditional insurance market, given the market's inability to supply coverage in cases of large-scale disasters. It is well-known that disaster insurers fear not only the potential magnitude of damage of a given catastrophe, but also the unpredictable nature of a catastrophe. ${ }^{174}$ The basic idea is that, given the problems in supplying catastrophe insurance, governments can play a positive role by stimulating insurance markets (and thus

171. See id. at 248 n.2.

172. See Kirchgaessner, supra note 159, at 236.

173. Id. at 239-40.

174. Kunreuther, supra note 36, at 178-90. 
applying differentiated premiums) and keeping disaster insurance affordable. ${ }^{175}$

While there are strong arguments in favor of this type of government intervention, the literature on the topic is quite divided. Some have qualified these types of interventions as "private- and public- insurance responses, "176 others have more generally examined "public-private partnerships" consisting of various layers to provide comprehensive insurance against natural disasters. ${ }^{177}$

\section{Drawbacks}

Both in law and economics, there is criticism of the facilitative role of the government in stimulating insurance markets. ${ }^{178}$ Gron and Sykes argue that it would be unjust for the government to provide (re)insurance at a lower price than the market price. ${ }^{179}$ This would give the wrong signal to the market as far as stimulating insurability is concerned. Ad hoc solutions where compensation is provided to accident victims on an ex post basis are preferable because market participants would not believe that compensation is guaranteed by the government.

Dutch lawyers Ammerlaan and van Boom have been critical of the Dutch government's participation in reinsurance against terrorism. They argue that the premium demanded by the government is incorrect and that it is not the State's task to provide private insurance. ${ }^{180}$ Damage caused by terrorism should instead be financed through the public purse. ${ }^{181}$

It is striking that most of this criticism is not addressed against government intervention, but is based on the assumption that the government will not charge premiums that properly reflect market

175. See generally Howard Kunreuther, Reducing Losses From Catastrophic Risks Through Long-Term Insurance And Mitigation, 75 SOC. RES. 95 (2008).

176. See Levmore \& Logue, supra note 95, at 278 (discussing government-provided compensation in catastrophes, especially with respect to terrorism risk).

177. See Kunreuther \& Pauly, supra note 72, at 112-13.

178. See Michael J. Trebilcock \& Ronald J. Daniels, Rationales and Instruments for Government Intervention in Natural Disasters, in ON RISK AND DISASTER - LESSONS FROM HURRICANE KATRINA 89 (Daniels et al. eds., University of Pennsylvania Press, 2006).

179. See Gron \& Sykes, supra note 4, at 458 (questioning the wisdom of U.S. government insurance of airlines, noting that the government becomes a problem rather than a solution by subsidizing insurance and allowing airlines to externalize their risks).

180. Karin Ammerlaan \& Willem van Boom, De Nederlandse Herverzekeringsmaatschappij voor Terrorismeschaden en de rol van de overheid bij het vergoeden van terreurschade NEDERLANDS JURISTENBLAD 45/46: 2330-39 (2003).

181. Id. 
prices. It is a criticism shared by Levmore and Logue, who argue that the reinsurer of last resort regime only has its desired effect when it involves a substantial subsidy. ${ }^{182}$ They are skeptical of market intervention for terrorism insurance, arguing that "the market would likely have been able to provide the necessary coverage" even without the intervention. ${ }^{183}$

\section{Advantages}

The arguments in favor of intervention are the mirror image of those against: assuming that capacity on the private insurance market is severely lacking, insurance coverage for disasters would simply not develop without government intervention. ${ }^{184}$ On the condition that the government charges an actuarially fair premium for its intervention, government reinsurance is an adequate resolution to the uninsurability problem. ${ }^{185}$ Moreover, this type of government intervention has the advantage of avoiding ex post relief sponsored through the public purse.

Where the government acts as reinsurer, those who actually cause harm or bear risk can pay the premium, thus facilitating market solutions, providing incentives for prevention to potential victims, and avoiding the negative redistribution from tax payers to victims. ${ }^{186}$ "Thus a State intervention as reinsurer may avoid "catastrophic responses to catastrophic risks." "187 This is further supported by the fact that the government can diversify the risks over the entire population and spread past losses to future generations. This creates a form of cross-time diversification, which the private market could not achieve. ${ }^{188}$ Additionally, government participation in insurance programs is especially crucial in the context of terrorism, where the risk of terrorist attacks is partly under the government's control and

182. Levmore \& Logue, supra note 95, at 304 (arguing that without a meaningful subsidy, disaster insurance would still not be "available").

183. Id. at 311.

184. See Kunreuther, supra note 36, at 180-83; Harrington, supra note 38 , at $43-45$; Schwarze \& Wagner, supra note 33, at 167.

185. Faure, supra note 3, at 358.

186. Michael Faure \& Klaus Heine, Insurance Against Financial Crises, 8 N.Y.U. J. L. \& Bus. 117, 129 (2011).

187. Id. (citing Epstein, supra note 3, at 287); see also Kunreuther, supra note 72, at 113 (arguing that a government role in supply side assistance may avoid the inefficiencies and inequities associated with disaster assistance).

188. See Howard Kunreuther \& Erwann Michel-Kerjan, Challenges for Terrorism Risk Insurance in the United States, 18 J. ECON. PERSP. 201, 210 (2004). 
the government often has more information on ongoing terrorist activities. ${ }^{189}$

Notwithstanding the objections of some free-market scholars, the examples provided in Part I demonstrate the increasing popularity of government intervention in providing disaster insurance, either as reinsurer or primary insurer. These constructions have the advantage of leaving more of a place for market solutions. ${ }^{190}$ We will take a critical look at some of these constructions in Part III.

\section{CONDITIONS FOR A GOVERNMENT ROLE AS (RE)INSURER OF CATASTROPHIC RISKS}

The literature arguing in favor and against a government role as (re)insurer for catastrophic risks implicitly formulates a variety of conditions. In this section, we will examine the particular conditions that lead to the most efficient outcomes.

\section{A. Non-distortive Government Intervention}

Whether or not markets would develop without intervention is, of course, hard to judge and is largely an empirical question. For example, as far as terrorism is concerned, one can argue that there is overwhelming empirical evidence that after 9/11, insurance companies began cancelling terrorism coverage ${ }^{191}$ However, that does not necessarily mean that without government intervention the development of a market solution would have been impossible. The danger that insurers will overstate the uninsurability argument is always present since a partial government takeover of risk may suit their interests. ${ }^{192}$ Accordingly, arguments provided by insurers must be viewed with a degree of skepticism.

189. See generally Howard Kunreuther and Erwann Michel-Kerjan, Insurability of (Mega-) Terrorism Risk: Challenges and Perspectives, in 9 TERRORISM RISK INSURANCE IN OECD COUNTRIES 107 (OECD Publ'g, 2005) (arguing that the characteristics of terrorism require government participation in any terrorism insurance program to be based on public-private partnerships).

190. See Levmore \& Logue, supra note 95, at 303.

191. See Robert P. Hartwig, The Impact of the September 11 Attacks on the American Insurance Industry, in INSURANCE AND SEPTEMBER 11 ONE YEAR AFTER: IMPACT, LESSONS AND UNRESOlVED Issues 10, 29 (Patrick M. Liedtke \& Christophe Courbage eds., 2002).

192. See Levmore \& Logue, supra note 95, at 298. 


\section{B. Charging Risk-based Premiums}

Many law-and-economics scholars stress that insurance rates should reflect the risk as closely as possible ${ }^{193}$ because the premium provides a signal to individuals of the risks they actually face. A system of risk-based premiums will provide incentives to invest in cost-effective loss prevention measures. ${ }^{194}$

State-provided insurance should thus charge risk-based premiums to reflect the actual risk. ${ }^{195}$ If the government does not receive any premium for providing (re)insurance coverage, commercial reinsurers could not compete with the government, and the government-provided (re)insurance would amount to a subsidy. ${ }^{196}$ In some countries, this could be considered state aid for which particular procedures must be followed. ${ }^{197}$

\section{Stimulating Market Solutions or Providing Efficient Government Insurance}

(Re)insurance by the government should be organized in such a way that market solutions are still stimulated. If government intervention is too "simple," and imposes artificially low costs, it provides no incentives for the market to develop its own solutions. However, one should be slightly careful with this recommendation, taking into account the Swiss example. As discussed above, disaster insurance in the majority of Swiss cantons is offered by regional monopolies. This empirical evidence shows that the government monopoly may be superior when it is able to provide insurance more efficiently than the market due to lower costs of risk differentiation (after liberalization).

193. See, e.g., Wharton Risk MgMt. \& Decision Processes CTR., MANAging LARgeSCAlE Risks in a NeW ERA of CATASTRophes: INSURING, Mitigating AND FinANCing RECOVERY FROM NATURAL DiSASTERS IN THE UNITED STATES 363 (Wharton Risk Mgmt. \& Decision Processes Ctr. ed., 2008).

194. Kunreuther, supra note 72 , at 111.

195. Id.

196. Kunreuther \& Michel-Kerjan, supra note 188, at 204; Levmore \& Logue, supra note 95 , at 304.

197. See FAURE \& HEINE, supra note 33, at 19 (listing five criteria to determine when a national subsidy or regulation qualifies as state aid). 


\section{Leave Freedom with Insurers to Choose State Reinsurance ${ }^{198}$}

An important aspect of stimulating the market, rather than distorting it, is leaving the individual insuree with the freedom to decide whether or not to use State (re)insurance. Since the State should charge a (re)insurance premium that mimics the market, this freedom would allow an insuree to look for cheaper alternatives. Requiring individuals to use State-provided (re)insurance could endanger competition on the insurance markets.

\section{E. Temporary Character}

In principle, government intervention should also have a temporary character (there should be so-called "sunset provisions"), because permanent intervention could have a negative effect on competition. This, of course, only holds true if it is assumed that the failure of ordinary (re)insurance markets is caused by exceptional circumstances (such as the uncertainties that arose after 9/11).

\section{A TEST}

In Part I, we presented various types of government intervention that might stimulate insurability of catastrophic risks. At the end of that part, we mentioned our particular interest in models in which the government acts as a primary insurer, or as a reinsurer of last resort. We will now examine a few arrangements in which the government aims to stimulate insurability and apply the conditions discussed in Part III for efficient government intervention. We specifically examine intervention that solves problems on the supply side of the catastrophe insurance market.

It is not possible within the scope of this paper to critically analyze all of the various arrangements that exist in practice, some of which we presented in Part I. Accordingly, we have chosen specific arrangements that we consider representative of a particular compensation model. In Part IV.A, we will describe different kinds of government interventions. First, we look at two cases in which the government acts as a primary insurer-the California Earthquake Authority (CEA) and the Consorcio de Compensacióon de Seguros (CCS). Next, we examine a case where the government acts as reinsurer of last resort, mostly for natural catastrophes, the French Caisse Central de Réassurance (CCR). The role of government as a

198. Part III.D borrows from a book written by one of the authors, see BRUGGEMAN, supra note 8 , at 201 . To ease readability, quotation marks have been omitted. 
reinsurer of last resort has recently received a lot of attention because this model is often followed in the case of terrorism.

Finally, Part IV.B will then compare the different arrangements within the context of the conditions set out in Part III.

\section{A. Description}

\section{Government as Primary Insurer: CEA}

The CEA represents an instance where the government stepped into the private insurance market and assumed the risk of a potential natural catastrophe. The CEA is a privately funded organization managed by the State of California. ${ }^{199}$ The organization was established in September 1996, after the 1994 Northridge Earthquake, in order to sell residential earthquake insurance policies through participating insurance companies and encourage Californians to reduce their risk of earthquake losses. ${ }^{200}$ The CEA currently has a claims-paying capacity that exceeds nine billion dollars and writes off seventy percent of earthquake premiums. ${ }^{201}$ The CEA provides for deductibles of ten or fifteen percent. ${ }^{202}$

The State of California requires insurers doing business in the State to offer earthquake coverage in homeowners' policies, either directly or through the CEA. ${ }^{203}$ The CEA is empowered to set premiums and to bear risks, but a so-called "mini-policy" lays down which classes of real estate losses are covered. ${ }^{204}$ In addition, the premiums must be set on an actuarial basis. ${ }^{205}$ In practice, the quoted CEA premiums have been tempered so that regional price differences are moderated. The CEA may purchase reinsurance, but it does not have access to public funds. ${ }^{206}$ As a result, CEA resources are only adequate to compensate an event which is double the size of

199. Frequently Asked Questions, CAL. EARTHQUAKE AUTH., http://www.earthquakeauthority.com/index.aspx?id=78\&pid=1 (last visited Nov. 26, 2012).

200. Id.

201. Cal. Earthquake Auth., California EArthquake Authority: At-AGLANCE (2011), available at http://www.earthquakeauthority.com/UserFiles/File/Release/

CEA\%20AT\%20a\%20Glance\%20for\%202011\%20FINAL\%20101411-1.pdf.

202. Insurance Policy Information, CAL. EARTHQUAKE AUTH., http://www.earthquakeauthority.com/Ceapolicyinformation.aspx?id=2\&pid=2 (last visited Dec. 3, 2012).

203. Frequently Asked Questions, supra note 199.

204. Id.

205. Id.

206. CONG. BudGET OFF., supra note 74, at 39-41. 
the Northridge Earthquake. ${ }^{207}$ Beyond that level, policyholders will only receive partial compensation. ${ }^{208}$

Participation in the CEA is voluntary-companies may and do compete with the CEA, although this competition is mainly limited to low-risk locations. ${ }^{209}$ The CEA charges considerable premiums and many homeowners find these too high relative to the coverage provided. Consequently, the percentage of Californians with earthquake coverage (through the CEA or a private insurer) declined from $33 \%$ in 1996 to $12 \%$ in $2010 .{ }^{210}$ The CEA has been criticized for both its high deductibles and low compensation amounts. ${ }^{211}$

\section{The Government as Primary Insurer: $C C S$}

The publicly administered disaster financing program CCS was founded in 1954 as a corporation providing insurance against "extraordinary risks" - namely natural disasters and risks with "social repercussions" such as terrorism and riots. ${ }^{212}$ It also covers personal damage for extraordinary events taking place abroad if the insured resides habitually in Spain. ${ }^{213}$ The Spanish program offers a good example of a government collecting a fee or premium in exchange for the provision of insurance coverage.

This extraordinary risk coverage is a "mandatory additional coverage added to fire and natural perils, motor and railway vehicles and other property damage policies." ${ }^{214}$ The extra CCS premium is automatically included in the base policy's premium and varies according to the type of policy offered, although it reflects the base rate charged on the primary policy. ${ }^{215}$

$$
\begin{array}{ll}
\text { 207. } & \text { Id } \\
\text { 208. } & \text { Id } \\
\text { 209. } & \text { Id }
\end{array}
$$

210. Compare CAL. DeP'T OF INs., Earthquake Premium and Policy Count Data Call: Summary of 2010 Residential \& Commercial Market Totals (CAL. DEP'T OF INS., 2011), with CAL. DEP'T OF INS., Summary of 1996: Residential Market Totals (CAL. DEP'T OF INS., 2002), available at http://www.insurance.ca.gov/0400-news/0200-studies-reports/0300-earthquakestudy/index.cfm.

211. See e.g., Insure your Home Against Natural Disasters, U.S NEWS. (Nov. 2, 2012), http://money.usnews.com/money/personal-finance/articles/2012/11/02/how-to-insure-your-homeagainst-hurricanes-and-other-natural-disasters.

212. Paul K. Freeman \& Kathryn Scott, Comparative Analysis of Large-Scale Catastrophe Compensation Schemes, in 8 CATASTROPHIC RISKS AND INSURANCE 187, 201 (OECD Publ'g, 2005).

213. Id.

214. Id.

215. Id 
Prior to 1987, disaster insurance premiums were calculated as a percentage of property damage insurance premiums. This meant that the premium income was influenced by events unrelated to disaster insurance. In 1987, the CCS began setting its own premium, which is not risk-related and is equal for the entire country. For example, the extra premium for a personal insurance policy amounts to 0.005 per mille. ${ }^{216}$

"CCS payments are subsidiary to payments made by the private insurance industry" and the Consorcio only pays if the risk was not covered by private insurance (for example, for the poor who did not buy insurance) or if the private insurance company fails to pay due to insolvency. ${ }^{217}$ Typically, domestic insurers in Spain do not cover extraordinary risks, but issue policy documentation clearly stating that such losses are the responsibility of the Consorcio, to whom relevant claims should be addressed. ${ }^{218}$

Following Spain's accession to the European Union in December 1991, the legal nature of the CCS changed from being a State monopoly to a public business institution attached to the Ministry of Economy and Finance. ${ }^{219}$ The CCS now has its own legal capabilities with full capacity to act and assets independent from the State ${ }^{220}$ In addition, given the unique characteristics of the Consorcio, especially its high loss potential and very nature as a public entity, it is absolutely necessary for the Consorcio to count on an unlimited State guarantee. Nevertheless, the organizational structure and financial management of its resources has enabled the CCS to meet its claims obligations without making use of this guarantee in the more than half-century of its existence. ${ }^{221}$

Following 9/11 and the March 11 attacks in Madrid, which led to a hard cut in cover for non-passenger third-party liability concerning the risk of terrorism, the Spanish government asked the Consorcio to

216. Riesgos Extraordinarios: El Recargo y su Tarifa, CONSORCIO DE COMPENSACION DE SEGUROS, http://www.consorseguros.es/web/guest/ad_re_er (last visited Sept. 19, 2012) (discussing additional premiums for personal, property, home, business, car, and infrastructure insurance).

217. Freeman \& Scott, supra note 229, at 201.

218. Id. (adding that "[d]eductibles for property loss amount to $1 \%$ of the insured total and a minimum of $€ 150.25$ ”).

219. Ignacio Machetti, The Spanish Experience in the Management of Extraordinary Risks, Including Terrorism, in 8 CATASTROPHIC RISKS AND INSURANCE 337, 339 (OECD Publ'g, 2005).

220. Id.

221. See id. at 339-40. 
cover that risk on behalf of the State. ${ }^{222}$ The CCS fulfilled this task up to October 31,2002, when coverage became available on the private market. ${ }^{223}$ In addition, the Spanish Association of Insurance Undertakings signed an agreement with the CCS under which the Consorcio would cover the business interruption risk of companies freely joining the agreement as reinsurer. ${ }^{224}$ This agreement was in force until business interruption became integrated in the extraordinary risks coverage system. ${ }^{225}$

\section{The Government as Reinsurer of Last Resort: $\mathrm{CCR}^{226}$}

France has installed a publicly owned reinsurance company, the $\mathrm{CCR}^{227}$ In the French system, reinsurance is not compulsory, and insurers are free to contract with other private reinsurance companies. However, reinsurance with the state is particularly attractive, both because of the relatively low premiums it charges and because it can offer unlimited coverage resulting from a State guarantee in the event that the CCR exhausts its resources. A CCR official noted that insurance companies must transfer half of their natural catastrophe risk to the CCR in order to be covered under the State guarantee. ${ }^{228}$ The State thus intervenes as a reinsurer, or, more correctly, as a retrocessionaire of the CCR. In exchange for this State guarantee, the CCR pays a premium to the State, exactly as it would have done if it was protecting itself through an ordinary reinsurer (although the latter could not have delivered an unlimited guarantee). The reinsurance program is set up to allow insurers to manage policyholders' claims, since they have the best claims-paying experience and expertise. Coverage from the CCR takes effect after the insured pays a certain deductible. ${ }^{229}$

222. Id. at 340 .

223. Id.

224. Id.

225. Id.

226. Part IV.A.3 borrows from a book written by one of the authors, see BRUGGEMAN, supra note 8 , at 309-12. To ease readability, quotation marks have been omitted.

227. Decree No. 82-706 of 10 August 1982 on the Reinsurance Operations for the Natural Catastrophe Risks by the Caisse Centrale de Réassurance. Application of Article 4 of the Act No. 82-600 of 13 July 1982, JORF 11 August 1982.

228. U.S. GOV'T ACCOUNTABILITY OFFICE, GAO-05-199, REPORT TO THE CHAIRMAN, CommitTeE on Financial SERVices, House of Representatives: CATASTrophe Risk U.S. AND EUROPEAN APPROACHES TO INSURE NATURAL CATASTROPHE AND TERRORISM RISKS 34 (2005).

229. The CCR's coverage for natural disasters is unlimited because of the State guarantee. The deductible under the CCR reinsurance contract, therefore, represents the maximum 
Insurance companies that decide to utilize the state reinsurer are offered two types of contracts: quota-share contracts and stop-loss contracts. With a quota-share contract, the insurer cedes a certain proportion of the collected premiums to the reinsurer. In return, the reinsurer undertakes the payment of the same proportion of the losses. The reinsurer will then truly follow the fortunes of the insurer, since the latter has to cede a percentage of each of the policies in its portfolio. The risk of adverse selection is hereby avoided. The proportional coverage could vary between forty and sixty percent. On the other hand, with a stop-loss contract, the reinsurance company covers all claims that exceed an agreed upon multiple of annual premium income. The insurer will then be protected against the risk of multiple claims. In order to prevent insurers from buying their risksharing coverage from private reinsurers and using the CCR only for stop-loss cover, the two contracts were tied: stop-loss contracts were only offered to those insurance companies who also bought quotashare contracts from the CCR with a minimum participation of 40 percent. Jametti and von Ungern-Sternberg conclude that the combination of these two types of reinsurance necessarily implies that CCR (and ultimately the tax-payer) will bear most of the cost when a large-scale disaster occurs. ${ }^{230}$

In the first twenty years of its existence, the CCR did not accumulate any substantial level of reserves, despite the fact that the average claims-to-premium ratio of disaster insurance was only sixty percent. Very few changes to the reinsurance scheme were made, although the CCR reinsured mainly the bad risks, ${ }^{231}$ and excessively high compensation (twenty-four percent) was paid for (largely imaginary) administrative costs. ${ }^{232}$ In addition, the combined effects of changes in the market (mergers, freedom of services within Europe,

amount that an insurer will have to bear in the course of a year, regardless of how many losses occur.

230. Mario Jametti \& Thomas von Ungern-Sternberg, Disaster Insurance or a Disastrous Insurance - Natural Disaster Insurance in France 1 (CESifo GmbH, CESifo Working Paper No. 1303, 2004).

231. See VON UNGERN-STERnBERG, supra note 169, at 86. Von Ungern-Sternberg argues that since the insurers have the right, but not an obligation, to reinsure a share of their natural disaster risk with the CCR, they have a strong incentive to lobby the government to set high premiums for natural disasters. It is then in the insurers' interest to reinsure only a small part of their risks and keep the rest of the premiums for themselves.

232. The effective cost of disaster insurance for the private insurers were, of course, almost nil, since disaster insurance was simply added to already existing property insurance contracts. In comparison, Spain, which employs an identical system of premium collection, only has a five percent commission for administrative costs. 
among other changes) and the deterioration of the claims figures made it increasingly unsuitable for just a single scheme to be offered. As a result, from January 1, 1997 onwards, the CCR introduced new reinsurance conditions which paid greater attention to the nature of each ceding company's portfolio and enabled insurers to retain a larger proportion of the risks. ${ }^{233}$ Still, in 1999, the CCR was on the verge of bankruptcy after it was called upon to make a major withdrawal on its reserves. Several major events hit France in 1999flooding in the Aude department in the south during November (insured losses of $€ 240$ million), flooding following the Winter Storms Lothar and Martin (insured losses of $€ 240$ million), and damage following a significant hurricane in the French Antilles. At the same time, an unexpected peril-soil subsidence-appeared in 1989, inducing a gradual erosion of the CCR's reserves over time. The State guarantee was consequently called into play. As a result, other amendments to the reinsurance scheme needed to be made to better adapt to the market situation, such as modifying the underwriting conditions, changing the applied deductibles, changing the deductibles in case the municipality lacks a PPRN, ${ }^{234}$ recapitalizing its reserves (the government injected three billion French francs, or $€$ 460 million), and abolishing compensation for administrative costs. ${ }^{235}$

Von Ungern-Sternberg, amongst others, has concluded that these various amendments to the CCR scheme are the outcomes of flaws in the institutional setup. ${ }^{236}$ On the other hand, Cannarsa and others, backed up by the Insurance Journal and A.M. Best, have a very positive outlook on the CCR. ${ }^{237}$

233. Caisse Centrale de Réassurance, Les Catastrophes Naturelles en France 20 (2007) [hereinafter CCR].

234. The PPRN is the Plan for the Prevention of Foreseeable Natural Risks (Plan de Prévention des Risques Naturels Prévisibles) and is a specific plan that municipalities have to draw up concerning the prevention of catastrophic risks.

235. A. Erhard-Cassegrain, et al., Minitére De L'écologie Et Du Développement, Évolution du Régime D' Indemnisation des Catastrophes Naturelles (2004), available at http://temis.documentation.equipement.gouv.fr/documents/Temis/0063/Temis-

0063158/18088.pdf; CCR, supra note 233, at 21; Thomas von Ungern-Sternberg, Catastrophe Insurance: Spain vs. France, ORG. FOR ECON. CO-OPERATION \& DEV., http://www.oecd.org/ dataoecd/59/33/37781875.pdf (last visited Sep. 10, 2012); Suzanne Vallet, The French Experience in the Management and Compensation of Large Scale Disasters, in Catastrophic Risks and Insurance 293 (OECD ed., 2006); Mario Jametti \& Thomas von Ungern-Sternberg, Risk Selection in Natural Disaster Insurance-The Case of France, (CESifo, Working Paper No. 1683, 2006).

236. See VON UNGERN-STERNBERG, supra note 169, at 82-104 (discussing natural disaster insurance in France and the problems associated with the system).

237. See Cannarsa et al., supra note 40, at 43. 


\section{The Government as Reinsurer of Last Resort: Terrorism}

\section{i. TRIA}

The American Terrorism Risk Insurance Act of 2002 (TRIA) establishes a temporary program of shared public and private compensation for insured losses resulting from foreign acts of terrorism. ${ }^{238}$ The goal of the program is to "protect consumers by addressing market disruptions and ensure the continued widespread availability and affordability" of terrorism insurance and to "allow for a transitional period for the private markets to stabilize, resume pricing of such insurance, and build capacity to absorb any future losses." 239 TRIA essentially creates a federal backstop for terrorism insurance by providing financial support for payment of terrorism claims in the event of a fairly large terrorism incident. The program is similar to reinsurance in that it provides reimbursement to insurers after they pay claims to a specified level (the deductible) and in that insurers retain a portion of the risk (a co-pay). ${ }^{240}$ In contrast to reinsurance, insurers do not pay a premium to be eligible and the government does not establish any reserves. Instead, the costs of the TRIA program are borne by the taxpayers with some or all of the costs subject to recoupment. In short, TRIA offers an illustration of the federal government providing coverage above a baseline risk that remains under the coverage of private insurers. The federal government temporarily assumes the role of excess liability insurer (or as reinsurer of last resort), providing a cap on the losses for which the private insurance industry remains responsible in the event of a terrorist attack. ${ }^{241}$ While initially set to last for two years (with the expiration date set at December 31, 2005), it has been systematically extended ever since. ${ }^{242}$

238. Terrorism Risk Insurance Act of 2002, Pub. L. No. 107-297, § 201, 116 Stat. 2322, 2337 (codified at 28 U.S.C. $\S 1610$ (2002)). The TRIA act does not cover any of the September 11th losses.

239. Id.

240. Thomas Russell \& Jeffrey E. Thomas, Government Support for Terrorism Insurance, 15 CONN. INS. L.J. 183, 186 (2008).

241. Rabin \& Bratis, supra note 28, at 325.

242. See, e.g., President Signs TRIA Extension, Insurance J. OnLIne (Dec. 27, 2007), http://www.insurancejournal.com/news/national/2007/12/27/85948.htm (discussing 2007 extension through 2014). 
All insurers providing commercial ${ }^{243}$ property or casualty insurance are required to participate in TRIA. ${ }^{244}$ "The insurers must make terrorism insurance available to all policyholders," but are free to choose the applicable extra terrorism premium, which should not be excessive, inadequate, or discriminatory. ${ }^{245}$

"If a certified foreign act of terrorism causes losses in excess of [five million dollars], participating insurers must pay a certain amount in claims - a deductible-before federal governmental assistance can become available." ${ }^{246}$ This deductible is now set at twenty percent of the insurer's directly earned premiums during the preceding year. ${ }^{247}$ Eighty-five percent of losses above the deductible will be covered by the federal government, while the insurance industry contributes fifteen percent. There is an annual cap of $\$ 100$ billion to all aggregate insured losses.

In case the cap would be exceeded, Congress has the authority to decide who will pay and in what amounts: the Treasury Secretary shall determine the pro rata share of insured losses to be paid by each insurer that incurs insured losses under the program... Insurers that meet the deductible will not be liable for losses in excess of this cap. ${ }^{248}$

\section{ii. GAREAT $T^{249}$}

French primary insurers that offer fire insurance are required by law to provide terrorism coverage as well. In practice, coverage against acts of terrorism was generally included in all standard

243. TRIA only applies to commercial property and casualty insurance, which is defined to specifically include excess insurance, workers' compensation insurance, and during the first three years of the TRIA Program, surety insurance. Workers' compensation insurance mandatorily includes insurance against terrorism, even without TRIA. See HocKMAN ET AL., WORKERS' COMPENSATION TERRORISM REINSURANCE POOL FEASBILITY STUDY: SUMMARY OF FINDINGS AND CONCLUSIONS 1 (2004) (explaining how workers' compensation can deal with the problem of terrorism losses). TRIA does not apply to personal insurance, such as homeowners', automobile, or life insurance. Moreover, by law, the TRIA program does not apply to: federal or private crop insurance; private mortgage insurance, or title insurance; financial guaranty insurance offered by a monoline financial guaranty insurance corporation; insurance for medical malpractice; health or life insurance, including group life insurance; federal flood insurance; and reinsurance or retrocessional reinsurance.

244. BRUGGEMAN, supra note 8 , at 442 .

245. Id.

246. Id.

247. Id. at 443 .

248. Id.

249. The GAREAT section borrows from a book written by one of the authors, see BRUGGEMAN, supra note 8, at 309-12. To ease readability, quotation marks have been omitted. 
insurance policies, meaning that all private and commercial properties were generally covered against terrorism events. However, after the September $11^{\text {th }}$ attacks, reinsurers cancelled their terrorism coverage and many primary insurers that could not obtain reinsurance chose to stop offering (especially commercial) property insurance to avoid the mandatory terrorism coverage. According to French insurance industry officials, ${ }^{250}$ the French government responded to this situation by first temporarily requiring the extension of all contracts, and then beginning negotiations with the insurance industry to develop a more permanent solution. As a result, the GAREAT (Gestion de l'Assurance et de la Réassurance des Risques Attentats et Actes de Terrorisme) reinsurance pool was created jointly by insurers, reinsurers, and the CCR on January 1, 2002. The idea of GAREAT is based on the existing administrative structures of the insurance associations and the natural catastrophe program already in place in France. The goal of GAREAT is to cover acts of terrorism (including those involving the use of nuclear weapons) that cause damages on French territory and assimilated territories.

Though GAREAT membership is not mandatory for insurance companies operating in France, insurers affiliated with the national association of insurance companies (Fédération Francaise des Sociétés d'Assurances) and the main trade body for mutuals (Groupements des Entreprises Mutuelles d'Assurance) automatically qualify as members of the pool. Upon subscription to GAREAT, each member is liable in proportion to the amount of the premiums ceded to the pool with respect to the subscription year.

The GAREAT program is divided into two sections: "Large Risks" and "Small and Medium-Sized Risks." The Large Risks section entails all contracts which fall within the scope of application of the GAREAT pool and whose insured sums are in excess of $€ 20$ million. The Small and Medium-Sized Risks section includes contracts less than $€ 20$ million. This section will not be discussed further, since properties less than $€ 20$ million may be ceded to the pool on a voluntary basis.

Both sections are the subject of specific provisions and each section is divided into layers. The first layer of the program consists of co-reinsurance between the members of the pool. The losses to this layer are split between the members proportionally to their respective

250. See U.S. GAO, supra note 228 , at 39-40. 
shares. The next layers consist of reinsurance by professional reinsurers, who provide capacity in the form of Annual Aggregate XOL treaties. These layers are the subject of reinsurance treaties. The top layer consists of unlimited reinsurance granted by the CCR with a guarantee from the French state. This layer is the subject of a reinsurance treaty with the CCR. For this purpose, the CCR receives a premium from GAREAT.

In 2012, the co-reinsurance layer had a limit of $€ 400$ million for the entirety of the losses. The second, third, fourth, and fifth layers constitute the Annual Aggregate Excess of Loss reinsurance program taken out by GAREAT on the international reinsurance market. The second to fifth layers are each limited to $€ 400$ million. The sixth layer constitutes the top layer where the CCR provides coverage (with an unlimited guarantee from the French State), with an XOL threshold of $€ 2$ billion.

The figure below illustates the reinsurance scheme: ${ }^{251}$

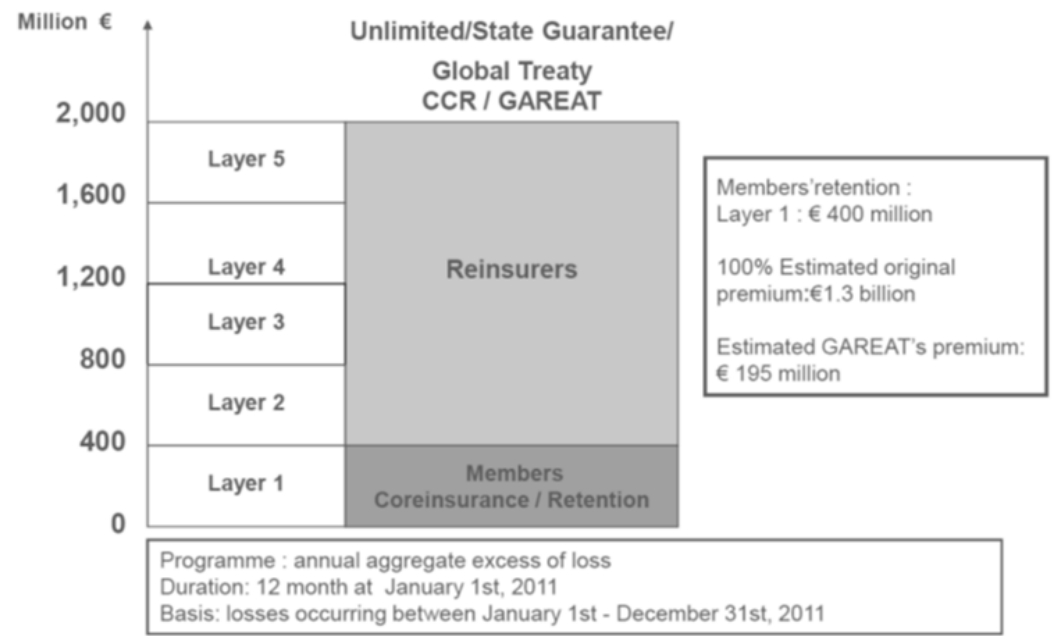

Fig. 2. GAREAT layer system.

251. Christine de Bondy, Secretary-General of GAREAT, Terrorism Schemes in the World: France: GAREAT, Questions and Issues before $6^{\text {th }}$ Meeting of the World Forum of Catastrophe Programmes 18 (Oct. 2011), available at http://www.ccrif.org/partnerships/WFCP/ Sessions/Day2/France_GAREAT_WFCP_Meeting_Oct_2011.pdf. 
The GAREAT premium rates are fixed by reference to the amount of the sums insured:

\begin{tabular}{|l|l|}
\hline Amount of total sums insured & GAREAT premium rate \\
\hline Sum insured $<€ 6$ mio (facultative session) & $3 \%$ \\
\hline$€ 6$ mio $<$ sum insured $<€ 20$ mio & $6 \%$ \\
\hline$€ 20$ mio $<$ sum insured $<€ 50$ mio & $12 \%$ \\
\hline$€ 50$ mio $<$ sum insured & $18 \%$ \\
\hline sum insured $>€ 750$ mio & quoted individually \\
\hline nuclear risks & $24 \%$ \\
\hline exceptional risks (e.g. captives) & special rating \\
\hline
\end{tabular}

Table 1. GAREAT premium layers.

Consequently, in 2007 GAREAT earned $€ 252$ million in premiums on 105,000 policies.

iii. $\mathrm{NHT}^{252}$

The Dutch government and the Dutch Association of Insurers agreed to set up a dedicated reinsurance company, called the Dutch Terrorism Risk Reinsurance Company (NHT), to cover insurance against terrorist acts in all classes of business. This step represented an intervention measure to address a market failure to supply terrorism risk coverage.

Since July 1, 2003, ${ }^{253}$ more than 250 insurance companies (ninetythree percent of all active Dutch insurers), the government, and some reinsurance companies participate in the NHT. The participating insurance companies cede all their terrorism exposure to the NHT pool, which acts as a reinsurance company. The overall capacity of is limited to $€ 1$ billion per calendar year. It was foreseen that this threshold of $€ 1$ billion would be gathered in three layers: the first $€$ 400 million will be reinsured by the participating primary insurers, while losses in excess of $€ 400$ million in the annual aggregate will be protected under a reinsurance market XOL program valued at $€ 300$ million, with any shortfall taken up by the Dutch government, acting as a reinsurer of last resort, up to another $€ 300$ million. The first layer applies a so-called threshold deductible, meaning that insurers bear the risk to $€ 7,5$ million.

252. The NHT section borrows from a book written by one of the authors, see BRUGGEMAN, supra note 8, at 377-79. To ease readability, quotation marks have been omitted.

253. The NHT became operational on July 1, 2003. It has been periodically extended for additional periods, and is expected to be further extended as long as market conditions require. 
The Dutch government charges a premium at a level intended to price itself out of the market when terrorism risk insurability is restored. From the period of July 1, 2003 until December 31, 2003, the government charged a premium of $€ 10$ million ( $€ 20$ million on a yearly basis). ${ }^{254}$ A system of descending premiums is used for increasing coverage. For example, the first part of coverage is relatively expensive-coverage of $€ 100$ million demands the same premium as the next increment of $€ 200$ million. Thus, an incentive is incorporated into the system in order to stimulate the recovery of commercial insurance: if individual reinsurers are capable of covering the risk, expectations are that they would offer coverage for a lower premium. This point of departure seemed to pay off, since a commercial reinsurer declared itself willing to cover the first $€ 100$ million of governmental coverage (namely between $€ 700$ and 800 million), delaying governmental intervention until the $€ 200$ million threshold. ${ }^{255}$

\section{B. Analysis}

The focus of this part is to compare the different arrangements that have been described in the previous paragraphs. The criteria established in Part III will serve as the framework for this comparison in order to evaluate which economic criteria have been fulfilled by the different kinds of government interventions.

\section{Non-distortive Government Intervention}

In the case of the CEA, it is doubtful whether there really was an absence of a market solution after the Northridge Earthquake, since other insurers provided coverage for earthquakes. Rather, it is an example where the government steps in as primary insurer and thus competes with other insurers. Whether the CCS had to be established in 1954 due to the absence of market solutions is not entirely clear. It is possible that a similar mechanism could have been provided by the market. This is similar to the case of the CCR. It is not so clear that without the CCR insurance of natural disasters would have been impossible. It is clear, though, that an unlimited guarantee (which is provided by France to the CCR) would never be provided by an ordinary reinsurer. Concerning the terrorism cases, it is clear that,

254. Parliamentary Proceedings of the Second Chamber of Representatives 2002-2003, 28 668, No. 2, 23 June 2003.

255. Parliamentary Proceedings of the Second Chamber of Representatives 2002-2003, 28 915, No. 5, 12 August 2003, p. 3. 
indeed, no market solution would have been possible. TRIA, for example, was clearly created because, after 9/11, insurance companies worldwide had withdrawn from covering terrorism risk, creating a market vacuum.

\section{Charging Risk-based Premiums}

The criteria for setting CEA premiums indicate that premium prices reflect risk. Indeed, the California Insurance Code states that "[r]ates established by the authority shall be actuarially sound so as to not be excessive, inadequate, or unfairly discriminatory. ${ }^{256}$ From this, one can conclude that premiums should in theory always reflect risk. However, this is not the case for the CCS. Since 1987, the CCS has set premiums that are unrelated to risk and equal for the entire country. The CCR's criteria for its premium prices are not entirely clear. It has to pay a premium for the provided State guarantee-which should, in principle, be market-based.

The terrorism cases are not identical. It is clear that the reinsurance provided by TRIA is an outright subsidy since insurers do not even pay a premium. The NHT, on the other hand, does charge risk-based premiums.

\section{Stimulate Market Solutions}

It is unclear how the CEA stimulates a market solution since the government competes with commercial insurers. Given that the CCS sets its own premiums that are unrelated to risk, the CCS does not really stimulate market solutions either. Recalling that the CCR benefits from an unlimited guarantee provided by the French government, which would never be provided by an ordinary reinsurer, it is also unclear how the CCR stimulates a market solution. In fact, the CCR is clearly not market competitive because its premiums are inherently more attractive due to their State guarantee. In that sense, the CCR is more of a market disruption than a solution.

An important feature of TRIA is that the State does not completely take over the risk since insurers must still pay a modest deductible. Nevertheless, one could argue that this still stimulates a market solution. Similarly, GAREAT could be regarded as a market stimulator to a certain extent, especially with regard to its first and second layers. However, GAREAT's reliance on state-guaranteed,

256. CAL. INS. CODE $\S 10089.40$ (2010). 
unlimited reinsurance granted by the CCR reduces the extent to which GAREAT indeed stimulates market solutions. The NHT, on the other hand, stimulates market solutions because it seems to set premiums in such a way that it also becomes attractive for private (re)insurers to develop their own insurance products.

\section{Leaving Freedom for Insurers to Choose State Reinsurance}

The freedom to join the CEA is relative since insurers are required to offer earthquake coverage. The CCS, on the other hand, establishes an arrangement in which insurers have the freedom to choose. In the case of the CCR, it is not particularly clear. Insurers have freedom to contract with private reinsurance companies, but some sources argue that insurance companies would have to transfer at least half of their natural disaster risk to the CCR. The three terrorism cases provide a clear example of schemes in which the government leaves the freedom with the insurers to participate or not.

\section{Temporary Character}

The CEA, CCS, and CCR do not seem to have a temporary character.

TRIA was initially established as a temporary program, but has since been continually extended. GAREAT was never established as a temporary program. The projected duration of the NHT is unclear, but it may be temporary given its premium structure and the strong incentives it sets to create market solutions.

\section{Summary}

We have presented various examples where the government provides some kind of intervention, usually to supplement insurance coverage in the compensation of disasters. These examples and the subsequent analyses could easily be extended to other cases as well. ${ }^{257}$ All we wish to show with these examples is that, in fact, no matter what type of structure is followed, there are some striking similarities and differences. It is remarkable that a premium is not always charged for government intervention (as in TRIA) and that in cases

257. For further examples of how to improve the management and insurability of largescale disasters, see Alberto Monti, Public-Private Initiatives to Cover Extreme Events, 5 THE GENEVA REPORTS: RISK AND INSURANCE RESEARCH 27 (2011); Alberto Monti, Climate Change and Weather-Related Disasters: What Role for Insurance, Reinsurance, and Financial Sectors?, 15 HASTINGS W.NW. J. ENVT'L POL'Y 151 (2009). 
where this premium is charged, it is doubtful that the premium actually reflects risk. Moreover, in some cases, the government in fact competes with the market (CEA) and in other cases merely provides a government guarantee because otherwise an insurance cartel could simply refuse to provide coverage altogether. ${ }^{258}$ In those cases, government intervention is problematic in the sense that one can wonder to what extent it actually stimulates a market solution. Moreover, in practice, none of the solutions presented has a temporary character.

If one would compare the performance of government acting as primary insurer (for example, the CEA and CCS), our examples seem to be doing relatively poorly since they do not have a temporary character and do not stimulate market solutions. However, on the basis of these results, one should be careful in concluding that this type of government intervention is therefore necessarily inferior to the role of government acting as reinsurer of last resort. After all, there are other cases where government monopolies have done very well in avoiding the charity hazard and in stimulating prevention. ${ }^{259}$ It is also striking that in the three cases we discussed concerning governments reinsuring the terrorism risk, there are some similarities and differences. In all three cases there was a clear absence of a market solution since the traditional insurers refused to cover terrorism risk after 9/11. Also, in all three schemes the government leaves the freedom to join with the insurers. However, only the Dutch scheme (NHT) seems to set premiums in such a way that it becomes attractive for commercial (re)insurers to develop their own insurance products. This is, as we just mentioned, obviously not the case in the United States, where TRIA basically provides gratis reinsurance.

Each of the examples provided shows that it is difficult to structure government intervention in a way that corresponds completely with economic principles. To some extent this is not surprising since the intervention of government in stimulating insurance markets may always have the character of a subsidy. These

258. This is, for example, the case in the Netherlands where crop insurance is covered through Agriver with a government guarantee. See Véronique Bruggeman, Michael G. Faure \& Karine Fiore, The Government as Reinsurer of Catastrophe Risks?, 35 THE GENEVA PAPERS 369, 383-84 (2010) (explaining that crop insurance is covered through Agriver with governmental guarantee in the Netherlands).

259. See, e.g., Emons, supra note 153, at 249-50; see also generally Raschky, supra note 108 (comparison of risk transfer systems indicate that government intervention may not exacerbate the charity hazard). 
(preliminary) results do give some support to those who were critical of government intervention in the first place. ${ }^{260}$

The results from this modest comparison of the cases discussed in this part can be summarized as follows:

\begin{tabular}{|l|c|c|c|c|c|}
\hline & $\begin{array}{l}\text { Non- } \\
\text { distortive } \\
\text { government } \\
\text { intervention? }\end{array}$ & $\begin{array}{l}\text { Premium } \\
\text { Reflect } \\
\text { Risk? }\end{array}$ & $\begin{array}{l}\text { Stimulate } \\
\text { Market } \\
\text { Solution? }\end{array}$ & $\begin{array}{l}\text { Temporary } \\
\text { Character? }\end{array}$ & $\begin{array}{l}\text { Freedom } \\
\text { for } \\
\text { Insurer? }\end{array}$ \\
\hline CEA & - & + & - & - & $+/-$ \\
\hline CCS & $+/-$ & - & - & - & + \\
\hline CCR & $+/-$ & $+/-$ & - & - & $+/-$ \\
\hline TRIA & + & - & $+/-$ & $+/-$ & + \\
\hline GAREAT & + & $+/-$ & $+/-$ & - & + \\
\hline NHT & + & + & + & $+/-$ & + \\
\hline
\end{tabular}

Table 2. Comparison of the Six Cases

\section{CONCLUDING REMARKS}

Compensation for victims of catastrophes is a hot topic in many countries. This is due both to the damage in the aftermath of 9/11 and the increasing number of natural disasters that have affected the United States, Asia, and Europe. Accordingly, there has been an increasing amount of legislative intervention to stimulate insurance markets in public-private partnerships. The reactions in the literature to these types of constructions vary: some economic literature relying largely on market solutions is quite critical of this intervention, whereas other, more insurance-related literature argues that these types of government intervention should be welcomed since they increase the insurability of risks that would otherwise be uninsurable. The aim of our paper was to add to that debate by looking at specific cases where the government acts either as a primary insurer or as a reinsurer of last resort. Indeed, to some extent the arguments in favor of or against government acting as a (re)insurer of catastrophe risks play at a high level of abstraction.

Of course, we have merely discussed a few of the possible forms of government intervention, most of them focusing on the supply side. Other literature discusses many additional alternatives, some of which focus on the demand side. Some examples include tax reductions for victims of catastrophes and outright subsidies to

260. See Role for Government, supra note 4, at 44-51; see also Levmore \& Logue, supra note 95 , at $308-09$. 
charitable organizations. ${ }^{261}$ If compensation of victims is the main goal, other structural arrangements are also possible, such as in the sphere of social security. ${ }^{262}$ Discussing all of these alternatives was outside the scope of our Article.

On the basis of theoretical law-and-economics literature, we posited a few conditions for efficient (or at least minimally disruptive) government supplementation of disaster insurance markets. For example, one important question is whether the government intervention is absolutely necessary - in other words, would a similar market solution have emerged without the intervention? Insurers may argue that they consider a risk uninsurable and thus call on government relief, but this does not necessarily mean the risk was actually uninsurable. Also, effective intervention means that a government asks for a premium price that mimics the market price. However, that supposes that one can actually know the price of an actuarially fair premium, which may be difficult in some cases. Moreover, as demonstrated by many of the examples we discussed, sometimes the government simply does not want to ask for an actuarially fair premium, since doing so may jeopardize the affordability of the scheme (premiums may become prohibitively high). If that is the case, one could question whether the government should intervene by providing gratis reinsurance or whether specific differentiated subsidies should be provided to individuals to allow them to purchase differentiated insurance contracts. ${ }^{263}$ The examples in this paper show that it is difficult in practice to structure government intervention in a way that corresponds with principles of economic efficiency. To some extent, this may not be surprising; some types of government intervention aim not only at efficiency, but also at redistribution. However, the question again arises whether acting as reinsurer of last resort is the most effective way of redistributing money to victims of catastrophes. We have argued that this intervention may be less distortive than ex post relief. By stimulating or backing up insurance markets, at least some differentiation of risks is possible-which is usually totally absent in the case of ex post relief. Regardless, many of the examples we discussed indicate that intervention as reinsurer of last resort often amounts to a state subsidy.

261. Levmore \& Logue, supra note 95, at 308-09.

262. See Langendonck, supra note 21, at 187-97 (discussing funding options at the international level).

263. As recently suggested by Kunreuther. 
Based on analysis of specific cases where the government acts as (re)insurer of catastrophic risks, we argue that there may be fewer reasons for economists' traditional objections against government intervention. The Switzerland example clearly shows that it may be possible to have an efficient public insurance monopoly that prevents catastrophic risks and the charity hazard more effectively than commercial insurance markets. Moreover, reality shows that politicians will always find it hard to resist ex post relief despite the objections of economists. Even though government acting as (re)insurer of catastrophic risk may not always completely comply with economic principles, it is at least far superior to the Santa Claus model of ex post relief. In the future, given the expectation that many countries may be confronted with huge amounts of catastropherelated damage, government-supported insurance mechanisms certainly deserve more attention. 